\title{
A Summary of Available Information on Ferrocyanide Tank Wastes
}

\author{
L. L. Burger \\ D. A. Reynolds ${ }^{1}$ \\ W. W. Schulz ${ }^{2}$ \\ D M. Strachan
}

October 1991

Prepared for the U.S. Department of Energy under Contract DE-AC06-76RLO 1830

Pacific Northwest Laboratory

Richland, Washington 99352

1) West inghouse Hanford Company

2) Consultant 


\section{Summary}

Ferrocyanide wastes were generated at the Hanford site during the mid to late 1950 s to make more tank space available for the storage of high level nuclear waste. The ferrosyanide process was developed as a method of removing ${ }^{137} \mathrm{Cs}$ from existing waste solutions and from process solutions that resulted from the recovery of valuable uranium in waste tanks.

During the course of the research associated with the ferrocyanide process, it was discovered that ferrocyanide materials when mixed with $\mathrm{NaNO}_{3}$ and/or $\mathrm{NaNO}_{2}$ exploded. This chemical reactivity became an issue in the 1980 s when the safety associated with the storage of ferrocyanide wastes in Hanford tanks became prominent. These safety issues heightened in the late 1980s and led to the current scrutiny of the safety associated with these wastes and the current research and waste management programs.

Ferrocyanide chemistry suggests that sodium nickel ferrocyanide is the principal precipitate originally formed in the waste treatment process. No solubility data or sample analyses have been obtained to confirm this hypothesis.

Over the past three years, numerous explosive tests have been carried out using milligram quantities of cyanide compounds. These tesis provide information on the nature of possible tank reactions. On heating a mixture of ferrocyanide and nitrate or nitrite, an explosive reaction normally begins at about $240^{\circ} \mathrm{C}$, but may occur well below $200^{\circ} \mathrm{C}$ in the presence of catalysts or organic compounds that may act as initiators. The energy released is highly dependent on the course of the reaction. Three attempts to model hot spots in local areas of the tanks indicate a very low probability of having a hot spot large encigh and hot enough to be of concern.

The main purpose of this document is to inform the members of the Tank Waste Science Panel of the background and issues associated with the ferrocyanide wastes. Hopefully, this document fulfills similar needs outside of the framework of the Tank Waste Science Panel. 


\section{Contents}

Summary $\ldots \ldots \ldots \ldots \ldots \ldots \ldots \ldots \ldots \ldots \ldots \ldots \ldots \ldots \ldots \ldots \ldots \ldots \ldots \ldots$ iii

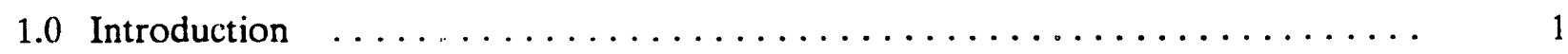

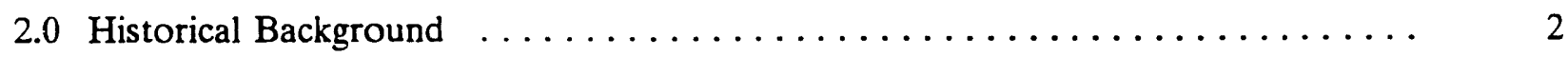

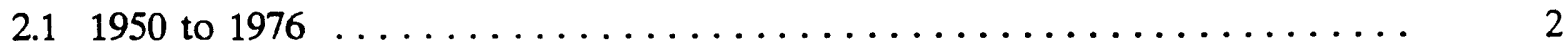

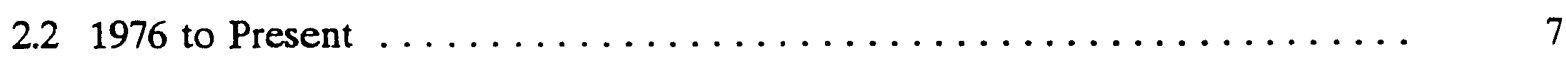

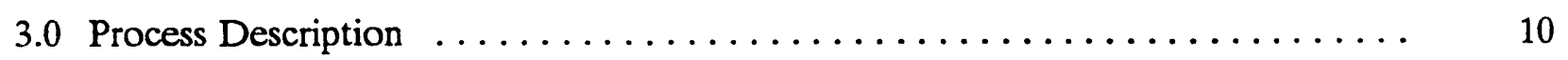

4.0 Ferrocyanide Chemistry and Reactions $\ldots \ldots \ldots \ldots \ldots \ldots \ldots \ldots \ldots \ldots$

4.1 The Metal Cyanide Complexes $\ldots \ldots \ldots \ldots \ldots \ldots \ldots \ldots \ldots \ldots \ldots \ldots \ldots$

4.2 Probable Tank Precipitates $\ldots \ldots \ldots \ldots \ldots \ldots \ldots \ldots \ldots \ldots \ldots \ldots \ldots$

4.3 Possible Reactions in Waste Tanks $\ldots \ldots \ldots \ldots \ldots \ldots \ldots \ldots \ldots \ldots$

4.4 Reactivity Measurements $\ldots \ldots \ldots \ldots \ldots \ldots \ldots \ldots \ldots \ldots \ldots \ldots \ldots \ldots \ldots \ldots$

4.4.1 Time-to-Explosion Tests $\ldots \ldots \ldots \ldots \ldots \ldots \ldots \ldots \ldots \ldots \ldots \ldots \ldots$

4.4.2 Thermal Measurements $\ldots \ldots \ldots \ldots \ldots \ldots \ldots \ldots \ldots \ldots \ldots \ldots \ldots \ldots \ldots$

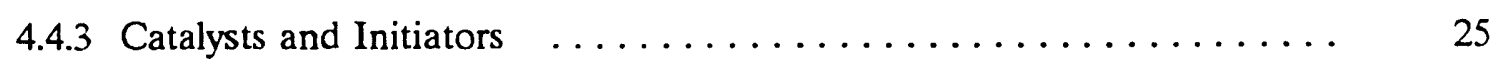

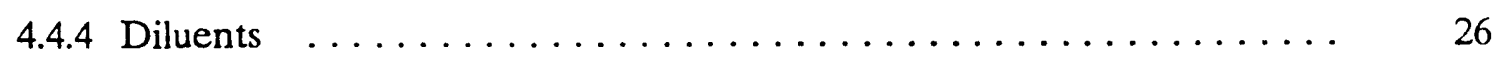

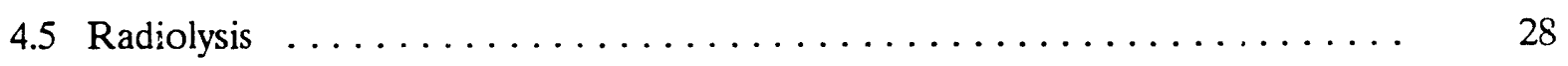

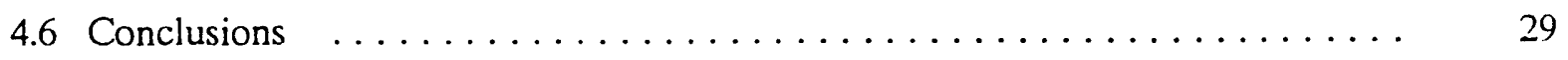

5.0 Heat Transfer in Tanks Containing Ferrocyanide $\ldots \ldots \ldots \ldots \ldots \ldots \ldots \ldots$

5.1 Modeling Calculations by D. A. Reynolds $\ldots \ldots \ldots \ldots \ldots \ldots \ldots \ldots \ldots \ldots \ldots$

5.2 Modeling Calculations by J. J. Barker $\ldots \ldots \ldots \ldots \ldots \ldots \ldots \ldots \ldots \ldots \ldots$

5.3 Modeling Calculations by J. M. McLauren $\ldots \ldots \ldots \ldots \ldots \ldots \ldots \ldots$ 


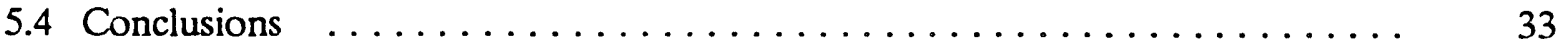

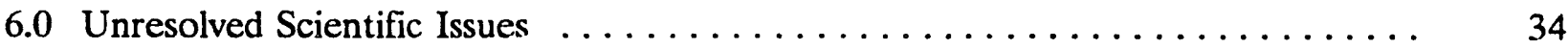

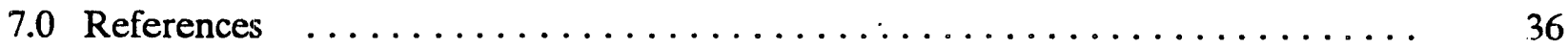




\section{Tables}

2.1 Key Historical Events in Production and Storage of Ferrocyanide Wastes at Hanford: 1950 to 1976

2.2 Key Historical Events in Production and Storage of Ferrocyanide Wastes at Hanford: 1976 to Present

3.1 Process History as Described by Abrams $\ldots \ldots \ldots \ldots \ldots \ldots \ldots \ldots \ldots \ldots$

4.1 Calculated Energy Release for Oxidation of Some Cyanides and

4.2 Time-to-Explosion Data for Small Samples $\ldots \ldots \ldots \ldots \ldots \ldots \ldots \ldots \ldots \ldots$

4.3 Quantity of Diluent Required to Prevent Propagation of Ferrocyanide Oxidation

5.1 Temperatures and Estimated Heat Load in Ferrocyanide-Containing Tanks .....

\section{Figures}

3.1 Nickel Ferrocyanide Scavenging of Neutralized Concentrated RAW Supernatant From Underground Storage

4.1 A Typical Time-to-Explosion Plot $\ldots \ldots \ldots \ldots \ldots \ldots \ldots \ldots \ldots \ldots \ldots \ldots \ldots \ldots \ldots \ldots$

4.2 Results from a Differential Scanning Calorimeter Experiment Using $\mathrm{Cs}_{2} \mathrm{NiFe}(\mathrm{CN})_{6}+$ Stoichiometric 50 mol\% $\mathrm{NaNO}_{3} / 50 \mathrm{~mol} \% \mathrm{NaNO}_{2} \ldots \ldots$

4.3 Results from a Differential Scanning Calorimeter Experiment Using $\mathrm{Cs}_{2} \mathrm{NiFe}(\mathrm{CN})_{6}+\mathrm{NaNO}_{2}$

4.4 Results from a Differential Scanning Calorimeter Experiment Using $\mathrm{K}_{2} \mathrm{NiFe}(\mathrm{CN})_{6}+50 \mathrm{~mol} \% \mathrm{NaNO}_{3} / \mathrm{NaNO}_{2}$

4.5 Results from a Differential Scanning Calorimeter Experiment Using $\mathrm{Na}_{2} \mathrm{NiFe}(\mathrm{CN})_{6}$ and $50 \mathrm{~mol} \% \mathrm{Na}_{2} \mathrm{NiFe}(\mathrm{CN})_{6}$ and $50 \% \mathrm{NaNO}_{3} / \mathrm{NaNO}_{2} \ldots$

4.6 Results from a Differential Scanning Calorimeter Experiment Using $\mathrm{NaNiFe}(\mathrm{CN})_{6}$ and $50 \mathrm{~mol} \% \mathrm{NaNO}_{3} / \mathrm{NaNO}_{2}$ 
4.7 Results from Differential Scanning Calorimeter Experiments

Using $\mathrm{Cs}_{2} \mathrm{NiFe}(\mathrm{CN})_{6}[\mathrm{FeCN}]$ and $50 \mathrm{~mol} \% \mathrm{NaNO}_{3} / \mathrm{NaNO}_{2}$ at Different

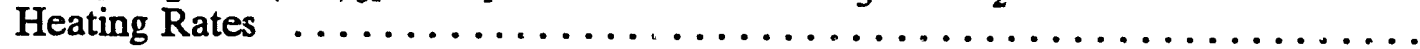

4.8 Results from a Scanning Thermogravimetric Experiment Using

$\mathrm{Cs}_{2} \mathrm{NiFe}(\mathrm{CN})_{6}$ and $50 \% \mathrm{NaNO}_{3} / \mathrm{NaNO}_{2}$ 


\subsection{Introduction}

Twenty two of the Hanford Site single-shell tanks contain a total of more than 900 metric tons (100 tons) of $\mathrm{Cs}_{2} \mathrm{NiFe}(\mathrm{CN})_{6}, \mathrm{Ni}_{2} \mathrm{Fe}(\mathrm{CN})_{6}$, and possibly other ferrocyanide compounds. These ferrocyanide solids were introduced into the Hanford tanks as the result of scavenging operations conducted from 1954 to 1957 to remove ${ }^{137} \mathrm{Cs}$ from liquid wastes produced when uranium values were recovered from early-day Hanford Bismuth Phosphate Process solid wastes. Later (1957 to 1976), other Hanford Site wastes containing varying concentrations of $\mathrm{NaNO}_{3}$, $\mathrm{NaNO}_{2}, \mathrm{NaAlO}_{2}$ and $\mathrm{NaOH}$ were added to and removed from the tanks containing the ferrocyanide solids.

Since at least 1957, it has been known that mixtures of ferrocyanide compounds and solid nitrate and nitrite compounds can react violently when heated to about $300^{\circ} \mathrm{C}$ (Hepworth, McClanahan, and Moore 1957). The potential for and consequences of the occurrence of an explosive reaction involving ferrocyanide wastes has been and is a continuing concern of the Department of Energy and its Hanford Site contractors as well as the Washington State Department of Ecology, various other Federal agencies, politicians, the media, and the general public.

Scientific investigations are being conducted to provide a fundamental understanding of the kinetics, energetics, and other characteristics of chemical reactions involving ferrocyanide compounds with solid nitrate and nitrite compounds. The Tank Waste Science Panel was commissioned to include in its purview the status, progress, and direction of these scientific studies.

This paper was prepared to provide historical and other background information on the origins and known properties of the ferrocyanide wastes to members of the Tank Waste Science Panel. Section 2.0 provides a chronological listing and discussion of significant historical events involved in the generation and management of the ferrocyanide wastes. Details of the ferrocyanide scavenging processes used from 1954 to 1957 to remove radiocesium from Metal Recovery Process wastes are summarized in Section 3.0. Section 4.0 is a synopsis of the presently known available scientific data concerning properties and reactions of ferrocyanide compounds with solid nitrate and nitrite compounds. In Section 5.0, the heat transfer aspects of the ferrocyanide waste problem are discussed as a basis for the most credible accident scenario. Finally, key unresolved scientific issues are described in Section 6.0. 


\subsection{Historical Background}

The history of the use and consequences of Nickel Ferrocyanide Precipitation Processes at the Hanford Site divides conveniently into two periods:

- 1957 to 1976

- 1976 to Present

In the earlier period, incentives and processes for using nickel ferrocyanide precipitation to remove ${ }^{137} \mathrm{Cs}$ from aging Bismuth Phosphate Process wastes were recognized and developed. During this early period, also, use of nickel, zinc, and other ferrocyanides for recovery of ${ }^{137} \mathrm{Cs}$ for possible commercial irradiation applications were studied, and the first observations were made at Hanford of the explosive decomposition of ferrocyanide-nitrate mixtures when heated to moderately high temperatures. The latter period begins in 1976 when preparation of the Draft Hanford Site Defense Waste Environmental Impact Statement (HDW EIS) entailed consideration of the safety hazards posed by possible vigorous reaction of the ferrocyanide solids in certain Hanford tanks. Concern about the possible occurrence of such vigorous exothermic reactions, of course, persists to this day and is now part of the concern of the Tank Waste Science Panel.

Tables 2.1 and 2.2 provide a brief capsule-like summary of key events in both the 1950 to 1976 and 1976 to Present periods regarding the generation and management of ferrocyanide wastes at the Hanford Site. These tables are compiled from data noted in the original references (cited in the tables) and from a chronological listing compiled by Mihalik (1989). The following text expands upon the events listed in Tables 2.1 and 2.2.

\subsection{0 to 1976}

In the United States in the early 1950 s there were strong incentives indeed, economic as well those deriving from Cold War issues, to recover uranium from the neutralized Bismuth Phosphate Process wastes produced from the first days of the Hanford Site and stored in underground single shell tanks. The Bismuth Phosphate Process was used to recover plutonium but not uranium values from $\mathrm{HNO}_{3}$ solutions of irradiated uranium metal. Because of the low power levels of the early-day defense nuclear reactors, the discharged fuel elements still contained most of the original precious fissile ${ }^{235} \mathrm{U}$ content.

Intense research and development efforts were performed at the Hanford Site in the late 1940s and early 1950s to develop a tributyl phosphate (TBP) solvent extraction process for recovering and purifying uranium from the retrieved and acidified Bismuth Phosphate Process sludges. Such sludges, formed when the acidic Bismuth Phosphate Process wastes were made alkaline, contained uranium, iron, and other hydrated metal oxides. Concomitant with the research effort, solvent extraction process equipment was installed in the Hanford $U$ plant, a plant originally built for operation of the Bismuth Phosphate Process but never used for that purpose. All this effort culminated in the 1950 to 1951 period when plant-scale uranium extraction operations started. 
Table 2.1. Key Historical Events in Production and Storage of Ferrocyanide Wastes at Hanford: 1950 to 1976

Date

1951

1954

$1955-1957$

$1957-1976$

1957

1957

1962

\section{Event and Reference}

Mound Laboratory scientists report on effectiveness of ferrocyanide precipitation processes for removing ${ }^{137} \mathrm{Cs}$ from alkaline waste solutions. (Mound Laboratory 1951)

Hanford scientists summarize results of a Nickel Ferrocyanide Scavenging Process tested successfully with both simulated and actual Metal Recovery Process waste solutions. (Burns, Brandt, and Clifford 1954)

Nickel Ferrocyanide Scavenging Process applied on a plant-scale to remove ${ }^{137} \mathrm{Cs}$ from both as-produced U Plant waste and from those produced in the 1952-1954 time frame. (Abrams 1956; Sloat 1955; Smith and Coppinger 1954; Schulz 1955)

Various types of Hanford defense wastes containing a wide range of $\mathrm{NaOH}$ concentrations are introduced into and removed from many of the underground tanks containing ferrocyanide solids.

Bench-scale development of a Zinc Ferrocyanide Scavenging Process for recovery of ${ }^{137} \mathrm{Cs}$ from neutralized Hanford PUREX process high-level waste. (Van Tuyl 1957a,b)

Scientists developing the Zinc Ferrocyanide Scavenging Process observe that mixtures of ferrocyanides, including $\mathrm{Cs}_{2} \mathrm{NiFe}(\mathrm{CN})_{6}$, and nitrate salts explode when heated to approximately $350^{\circ} \mathrm{C}$. (Hepworth, McClanahan, and Moore 1957)

An evaluation of potential hazards to be encountered in the projected In'Tank Solidification Program called attention to the potential explosive reaction of ferrocyanide solids and recommended follow-on laboratory studies. Such follow-on studies were not performed. (Backman, Johnston, and Rathvon 1964) 
Table 2.2. Key Historical Events in Production and Storage of Ferrocyanide Wastes at Hanford: 1976 to Present

Date

1976

1983

1983

1983

1984

1984

1986

\section{Event and Reference}

H. H. Van Tuyl, one of the principal investigators in the 1957 zinc ferrocyanide precipitation studies, starts contributing to the preparation of the draft of the Hanford Defense Wastes Environmental Impact Statement. Van Tuyl calls out the potential for explosive reactions between stored ferrocyanide wastes and nitrate compounds as the Worst Credible Accident Scenario for single-shell tank wastes.

Van Tuyl, in a February 3, 1983 letter to Rockwell Hanford Operations, expresses concern about potential ferrocyanide waste safety p:oblems. Van Tuyl's main concern is that the risks posed by the ferrocyanide solids have not been fully evaluated. (Schulz 1989)

At direction of Rockwell management, W. W. Schulz meets with H. H. Van Tuyl, L. L. Burger, and L. Morgan, all of PNL, to address Van Tuyl's concerns. Schulz recommends funding for the proposed benchscale studies at PNL to evaluate the reactions between ferrocyanide compounds and nitrates/nitrites. (Schulz 1989)

In November, 1983, funds are provide for studies at PNL to study the explosive properties of nickel ferrocyanide solids and nitrate/nitr ite mixtures.

A preliminary study of the radiolytic behavior of a $\mathrm{Cs}_{2} \mathrm{NiFe}(\mathrm{CN})_{6}$ precipitate is performed. No decomposition of the precipitate was evident at an exposure of $2.0 \times 10^{8}$ rad. (Martin, Burger, and Morgan 1985)

A report in which the present knowledge of the explosive reactions of ferrocyanide wastes stored in Hanford single shell tanks is prepared. The energy that could be potentially released during a worst case scenario is estimated. The report is not given final approval until 1988. Funding for further laboratory work is not provided until 1988.

A report is issued in which the results are shown of a calculation of the radiation dose to a person living off site as the result of a ferrocyanide tank explosion. (Mishima, Sutter, and Halley 1986) 
Table 2.2. (contd)

Date

1988

1988

1989

1989

1989

1990

1990

1991

\section{Event and Reference}

The document summarizing the results of the ferrocyanide reactions with nitrate/nitrite is approved for public distribution (Burger 1984). Funding for additional bench-scale studies of the properties of ferrocyanide wastes is provided.

Burger and Scheele (1988) issue an interim report in which they discuss their newest results of further investigation of the explosive properties of ferrocyanide wastes.

New York Times publishes a series of articles in which the hazards posed by the wastes, including ferrocyanide wastes, in the Hanford tanks are discussed.

U. S. Congress creates Defense Nuclear Facilities Safety Board as an independent "watch dog" agency to review the safety of waste management facilities and practices at U.S. DOE sites.

Westinghouse Hanford Co. and DOE-RL personnel brief Washingtor State Department of Ecology staff on the status and progress of engineering and scientific work related to safe management of ferrocyanide solids in Hanford Site single shell tanks. (Mihalik 1989)

Consultants to Defense Ivuclear Facilities Safety Board are briefed on status and progress of bench scale studies of ferrocyanide solid properties and reactions.

The General Accounting Office of the U. S. issues a report on the management of wastes in Hanford Site tanks.

Tank Waste Science Panel commissioned to include ferrocyanide wastes in its purview.

Early on in the development of the Uranium Recovery Process it was recognized that the process would generate millions of gallons of waste, which would have to be either stored in underground tanks or otherwise disposed of (Burns, Brandt, and Clifford 1954). Then, as now, tank storage capacity at the Hanford Site was at a premium. This latter economic consideration prompted analyses and evaluations to determine if the liquid portion of the "neutralized" wastes from the Uranium Recovery Plant could, after proper treatment, be safely disposed of to the Hanford soil in full compliance with the then-existing regulations and policies. Such analyses showed that ground disposal would indeed be feasible provided the liquid wastes were treated before disposal to reduce the ${ }^{137} \mathrm{Cs}$ concentration to or below $0.1 \mu \mathrm{Ci} / \mathrm{mL}$. 
Following initial favorable results obtained by Mound Laboratory (1951) researchers, extensive bench-scale tests of the applicability of and conditions for ferrocyanide scavenging of ${ }^{137} \mathrm{Cs}$ from alkaline Metal Recovery Process wastes were performed by Burns, Brandt, and Clifford (1954). These tests confirmed that precipitation of several metal, e.g., nickel, copper, zinc, etc., ferrocyanides would reduce ${ }^{137} \mathrm{Cs}$ concentrations to or below the $0.1 \mu \mathrm{Ci} / \mathrm{mL}$ criterion. Further proof of the efficiency of ferrocyanide precipitation techniques for removal of radiocesium was obtained in a large-scale (50,000 gallons) test performed in the. U Plant (Burns, Brandt, and Clifford 1954).

The laboratory and pilot plant tests culminated in startup in 1954 of routine plant-scale use of a Nickel Ferrocyanide Scavenging Process for removal of radiocesium. Plant-scale cesium scavenging operations were performed both with as-produced Metal Recovery Plant wastes (in the $U$ Plant) and with previously-produced U Plant waste stored in underground tanks. During the period (1954-1957) that ferrocyanide scavenging operations were performed, various process changes were made. For example, less expensive $\mathrm{Na}_{4} \mathrm{Fe}(\mathrm{CN})_{6}$ was substituted for the initiallyused $\mathrm{K}_{4} \mathrm{Fe}(\mathrm{CN})_{6}$ (Abrams 1956) and $\mathrm{Ca}\left(\mathrm{NO}_{3}\right)_{2}$ and, later, $\mathrm{Sr}\left(\mathrm{NO}_{3}\right)_{2}$ were added to improve ${ }^{90} \mathrm{Sr}$ removal by precipitation of insoluble phosphates (Sloat 1955). Details, including which tanks are known or suspected to contain ferrocyanide solids, of the plant-scale scavenging operations are provided in Section 3.0.

For many years (1957 to about 1976) following completion of plant-scale ferrocyanide scavenging operations, several types of alkaline Hanford wastes of varying composition, especially $\mathrm{NaOH}$ concentration, were stored in many of the tanks containing settled ferrocyanide solids. Large amounts of $\mathrm{NaNO}_{3}$ and $\mathrm{NaNO}_{2}$ were introduced into the tanks containing ferrocyanide precipitates; in many cases, also, solids present in the added wastes settled on top of the ferrocyanide solids. Use of all single-shell tanks at the Hanford Site to contain newly-produced liquid wastes was discontinued in 1972. Since that time, a major effort to remove all pumpable liquids from the single-shell tanks has been performed and continues today. It is important to note that most, if not all, single-shell tanks still contain liquids that are held by capillary forces and cannot be removed by pumping.

Even while plant-scale ferrocyanide scavenging operations were in progress, various Hanford Site scientists were investigating the use of ferrocyanide precipitation processes for selective removal of ${ }^{137} \mathrm{Cs}$ directly from newly-generated Hanford Site PUREX plant high level waste (Hepworth, McClanahan, and Moore 195\%; Van Tuyl 1957a, b). The incentive for this research was the perceived large market for ${ }^{137} \mathrm{Cs}$ sources for commercial sterilization of foods, medical supplies, etc. Even though the research tests were very successful, commercial markets for encapsulated ${ }^{137} \mathrm{Cs}$ sources never materialized; and the zinc ferrocyanide scavenging process was never used routinely in the Hanford PUREX plant.

But, out of this research emerged a result which was to have a profound impact on the safc management and storage of the nickel ferrocyanide wastes. Scientists developing a calcinationchlorination process for converting $\mathrm{Cs}_{2} \mathrm{ZnFe}(\mathrm{CN})_{6}$ to $\mathrm{CsCl}$ sometimes observed explosions during 
heating of $\mathrm{Cs}_{2} \mathrm{ZnFe}(\mathrm{CN})_{6}$ precipitates (Hepworth, McClanahan, and Moore 1957). These investigators noted that two water washes of the ferrocyanide solids removed the $\mathrm{NaNO}_{3}$, which reacted explosively with $\mathrm{Cs}_{2} \mathrm{ZnFe}(\mathrm{CN})_{6}$.

\subsection{6 to Present}

Almost 20 years elapsed after the ferrocyanide solids were laid down in single-shell tanks before nickel ferrocyanide solids again became a waste management concern. In the mid-1970s the Department of Energy authorized two of its Hanford Site contractors, Rockwell Hanford Operations and the Pacific Northwest Laboratory, to begin preparation of a Draft Environmental Impact Statement (HDW EIS) for final disposal of various classes of iranford Site Defense Wastes. One part of such a HDW EIS is to list and evaluate maximum credible accident scenarios. Harold H. Van Tuyl (Schulz 1989), recalling his own experience with the explosive properties of $\mathrm{Cs}_{2} \mathrm{ZnFe}\left(\mathrm{CN}_{j_{5}}\right.$-nitrate mixtures, advised the preparers of the HDW EIS of his belief that explosion of mixed $\mathrm{Cs}_{2} \mathrm{ZnFe}(\mathrm{CN})_{6}-\mathrm{NO}_{3}^{-}$precipitates stored in some single-shell tanks was surely a credible accident scenario, indeed the maximum credible accident scenario.

Several years elapsed before Van Tuyl's concerns re: irfaced and were properly addressed. Indeed, it was not until 1983 when Var Tuyl wrote a formal letter (Schulz 1989) to the top management of Rockwell Hanford Operations, then the Operating and Management contractor at the Hanford Site, outlining his concerns about the continued safety of managing stored ferrocyanide wastes and asking that these concerns be addressed by appropriate bench-scale studies. Senior Rockwell Hanford Operations management directed W. W. Schulz, then Rockwell's Senior Scientific Advisor, to take the appropriate initial action to respond to Van Tuyl. Schulz called a meeting to discuss Van Tuyl's concerns and suitable follow-on action. Attendees at this meeting included L. L. Burger, L. G. Morgan, H. H. Van Tuyl, and W. W. Schulz. As a result of this meeting, W. W. Schulz (1989) prepared and issued a letter to Rockwell management summarizing the minutes of his April 1983 meeting with Pacific Northwest Laboratory personnel and strongly advising that the proposed bench-scale studies were needed and should be funded. Rnckwell management concurred with this judgement and provided funding for laboratory work to begin in November 1983.

As part of their preliminary experimental work, Burger and Martin at PNL performed some radiolysis work wherein nickel ferrocyanide precipitates were irradiated to doses as high as $2 \times 10^{+8} \mathrm{rad}$ using a ${ }^{60} \mathrm{Co}$ source. No radiolytic decomposition of the ferrocyanide solids was observed.

In November 1984, Burger (1984) prepared a report in which he summarized the current evaluation of potential explosive reactions involving ferrocyanide solids and nitrate salts. An important conclusion of this evaluation was that if the ferrocyanide solids were concentrated in a tank and in contact with nitrate salts at a sufficiently high temperature, an explosica wit' the energy equivalent to 36 tons of TNT could result. 
Burger's report (1984) was approved by both the appropriate PNL and Rockwell personnel for public release, but final clearance of the report was not granted. At that time, funding for further bench-scale investigations of the safety issues related to the storage of ferrocyanide solids was discontinued in the period 1985 to 1987.

Also, in the 1985 to 1987 time frame, and as part of their effort to write the HDW EIS, PNL scientists estimated the potential dose to people living outside the Hanford reservation from a release of radiation as the result of an explosive ferrocyanide-nitrate reaction. Final release of the HDW EIS was of particular significance since it informed the public of the potential for explosive reactions in those single-shell tanks containing ferrocyanide solids.

Events concerning the chemistry and reactions of ferrocyanide solids and the potential consequences of such reactions moved swiftly in the years 1988, 1989, and 1990. For example, 1988 marked a reversal of the 1985 decision not to release Burger's 1984 report to the ruiblic, and the report was released. Also, in 1988 Burger was funded to resume bench-scale investigations of the reactions of ferrocyanide solids with various nitrate compounds. Late in 1988 Burger and Scheele (1988) issued an interim report documenting results obtained to date. Results of a literature search disclosed that the lowest temperature at which a ferrocyanide solid reacted with any nitrate salt was observed to be $220^{\circ} \mathrm{C}$. In laboratory tests, exothermic reactions involving ferrocyanide solids and nitrate salts were not observed below $240^{\circ} \mathrm{C}$ and explosions were not observed below $340^{\circ} \mathrm{C}$.

Concurrent with the resumption of laboratory work, much action on the political and media fronts occurred in the 1988 to 1990 time frame:

- At the urging of Senator John Glenn (D, Ohio), the U. S. Senate passed legislation which created the Defense Nuclear Facilities Safeiy Board (DNFSB). Issues concerned with safe management and disposal of Hanford Site ferrocyanide solids received great attention during Senate confirmation hearings for the members of the DNFSB.

- The Naw York Times published a series of articles that probed exhaustively into issues concerned with potential reactions of ferrocyanide-nitrate mixtures in Hanford tanks.

- The Washington State Department of Ecology requested and received extensive and detailed briefings from DOE-RL, PNL, and Westinghouse Hanford Co. personnel concerning the status and progress of current and planned experimental investigation of conditions necessary for explosive reactions of ferrocyanide-nitrate mixtures.

- At the request of the newly-constituted DNFSB, personnel from DOE-RL, PNL, and Westinghouse Hanford Co. provided an updated review of the status of work related to safe management of ferrocyauide solids in Hanford tanks. This review was conducted in March 1990 to three DNFSB consultants. Personnel from the Washington State Department of Ecology and the U. S. General Services Administration (GAO) were also in attendance. The DNFSB consultants strongly endorsed the thrust of experimental work to understand the properties of ferrocyanide compounds and mixtures of ferrocyanide and nitrate salts. 
- Following the March 1990 briefing to the DNFSB consultants, a consultant to the GAO prepared an assessment for the GAO of the Hanford Site ferrocyanide solids issues. This report further focussed on the likelihood and potential consequences of an explosive ferrocyanide-nitrate reaction and urged accelerated studies to understand the limits of such reactions, conditions under which explosive reactions occurred, and ways to prevent explosions or, at least, to mitigate their effects.

- Finally, in February 1991, the scope of the Tank Waste Science Panel was expanded to include review of and recommendations for ongoing and new scientific investigations related to the composition, properties, and reactions of simulated and actual ferrocyanide solids in Hanford single-shell tanks. 


\subsection{Process Description}

The nickel ferrocyanide scavenging flowsheet has been described in three documents: Smith and Conpinger 1954, Sloat 1955, and Abrams 1956. Other documents are also available, but the legibility of some of these documents is poor (Finch 1953; Schmidt and Stedwell 1954; Sloat 1954; Stedwell 1954; Smith and Coppinger 1954; and Boucher and Ingalls 1955). In the first of these documents (Smith and Coppinger 1954), the feed to the process is described as follows:

"Since the TBP [tributyl phosphate] Plant feed compositions vary from batch to batch and since a portion of the waste has received a secondary concentration in the tank farm waste evaporators, the chemical concentrations of the waste may vary by a factor of two. The chemical compositions shown in Figure 1 are expected to be the average values encountered."

The referenced flow sheet has been reproduced in Figure 3.1. The $\mathrm{pH}$ of the feed from the TBP Plant was variable and although the target value was 8.5 , variations of $\pm 2 \mathrm{pH}$ units were common. Therefore, the flowsheet shows possible addition of either $\mathrm{NaOH}$ or $\mathrm{HNO}_{3}$. Either $\mathrm{K}_{4} \mathrm{Fe}(\mathrm{CN})_{6}$ or $\mathrm{Na}_{4} \mathrm{Fe}(\mathrm{CN})_{6}$ could be used in the process and one of these was adder in excess to the $\mathrm{NiSO}_{4}$. The order of addition of the ferrocyanide and $\mathrm{NiSO}_{4}$ in the TBP Plant was recommended by Burns, Brandt, and Clifford (1954), who recommended that the ferrocyanide be added to the acid waste before $\mathrm{pH}$ adjurtment. Schmidt and Stedwell (1954) also recommended reverse addition of $\mathrm{K}_{4} \mathrm{Fe}(\mathrm{CN})_{6}$ and nickel, i.e., addition of $\mathrm{NiSO}_{4}, \mathrm{pH}$ adjustment, and $\mathrm{K}_{4} \mathrm{Fe}(\mathrm{CN})_{6}$ addition.

The nicikel ferrocyanide scavenging process was changed when it was used with the ferrocyanide wastes already in tank storage. Sloat (1955) determined that there were three types of wastes existing in tanks at that time and that each required a different scavenging process. One waste type was strongly alkaline, $\mathrm{pH}=11$, and required the addition of $\mathrm{HNO}_{3}$ to bring the $\mathrm{pH}$ to $9.3 \pm 0.7$. Then, $0.005 \mathrm{M} \mathrm{Na}_{4} \mathrm{Fe}(\mathrm{CN})_{6}$ was added followed by the addition of $0.005 \mathrm{M}$ $\mathrm{NiSO}_{4}$. These wastes contained very little ${ }^{90} \mathrm{Sr}$ and, thus, the addition of $\mathrm{Ca}\left(\mathrm{NO}_{3}\right)_{2}$ was not needed to reduce the ${ }^{90} \mathrm{Sr}$ concentration.

The second set of tanks contained wastes with $\mathrm{pH}$ values between 8 and 10 . The $\mathrm{pH}$ was measured before the transfer so that flow rates of either $\mathrm{HNO}_{3}$ or $\mathrm{NaOH}$ could be calculated. These wastes contained substantial quantities of ${ }^{90} \mathrm{Sr}$, so the addition of $\mathrm{Ca}\left(\mathrm{NO}_{3}\right)_{2}$ was needed.

The third waste type had previously been scavenged using the ferrocyanide process, but the ${ }^{90} \mathrm{Sr}$ concentration had not been sufficiently reduced to allow the supernatant liquid to be sent to the cribs. Therefore, only $\mathrm{Ca}\left(\mathrm{NO}_{3}\right)_{2}$ addition was needed. Although Sloat states that no $\mathrm{pH}$ adjustment was needed, he also states that "the addition of $\mathrm{Ca}\left(\mathrm{NO}_{3}\right)_{2}$ would lower the $\mathrm{pH}$ and, hence, it is desirable to start with a solution that has a pH of about 9.5." This procedure was also recommended by Schulz (1955), who determined that the $\mathrm{pH}$ shift was due to the precipitation of the phosphoric acid, which was not completely dissociated at $\mathrm{pH}=9.3$.

Abrams (1956) provides a concise description of the changes in the development of the ferrocyanide precipitation process. His summary is shown as Table 3.1. It is not clear from this 


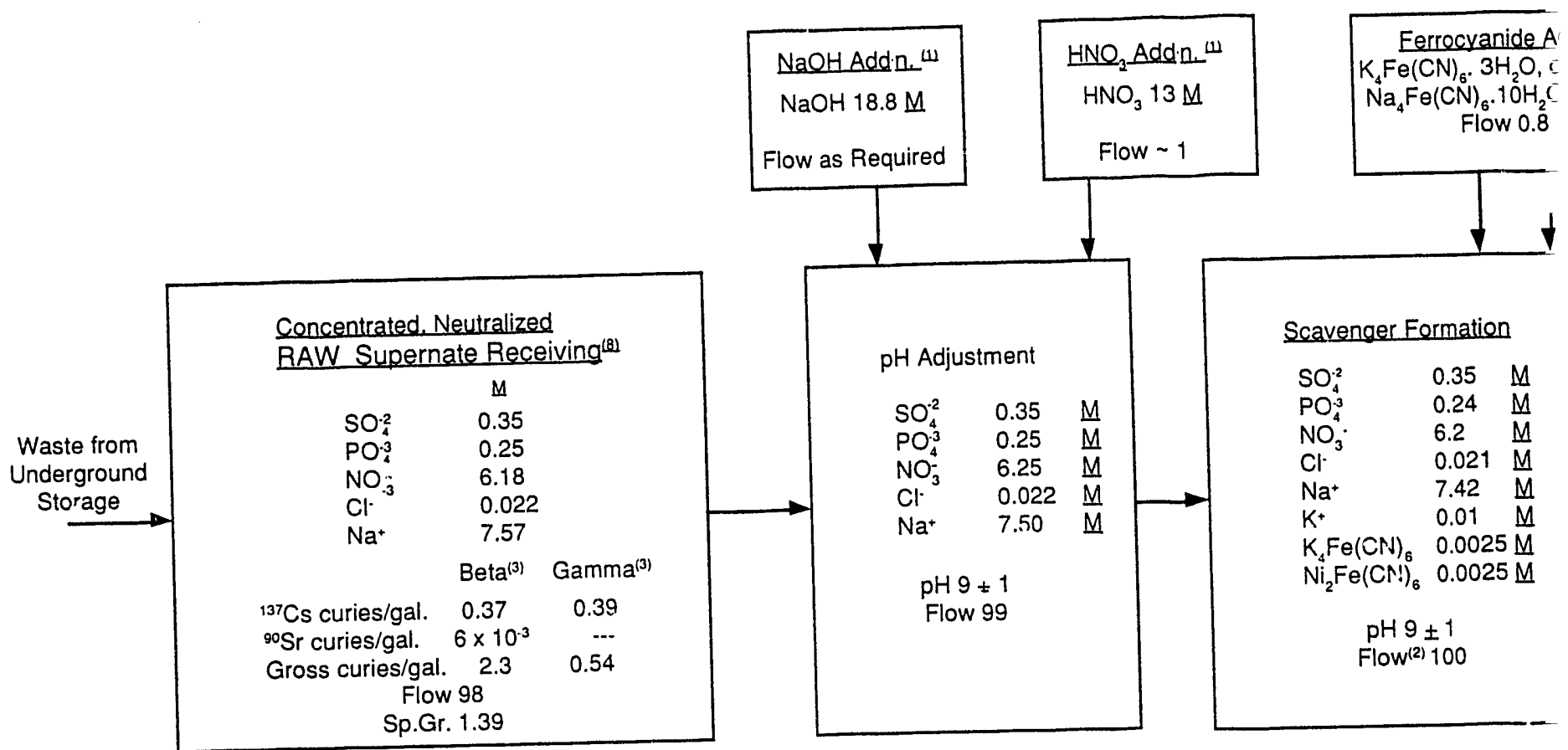

(1) Nitric acid and sodium hydroxide requirements will vary depending upon the $\mathrm{pH}$ of the waste processed. Assuming all waste will have a

(2) All flows are relative rates based on 100 flows of scavenged waste in the scavenger-formation step.

(3) The age of the RAW supernate processed will be at least two years. Fission product concentrations are based on a two-year-old waste pri approximately 200 and 3 , respectively, by the scavenging effect of alkaline insoluble materials during the waste neutralization step.

(4) Cesium and s':ontium decontamination factors, along wtih those for gross beta and gamma, are based on laboratory-scale studies discus

(5) The sludge volume shown above is based on laboratory-scale studies discussed in HW-31442 [Burns, Brandt, and Clifford (1954)]. In ad

(6) Essentially all of the ferrocynide will be present in the sludge. The anions associated with the ferrocynide are not positively known. Cesiu

(7) Laboratroy-scale studies indicate sludge settling rates of approximately 1 inch/hr.

(8) The chemical composition of the concentrated, neutralized RAW supernate is based on the TBP.HW \#4 Chemical Flow sheet. In actual 1 reagents required. 


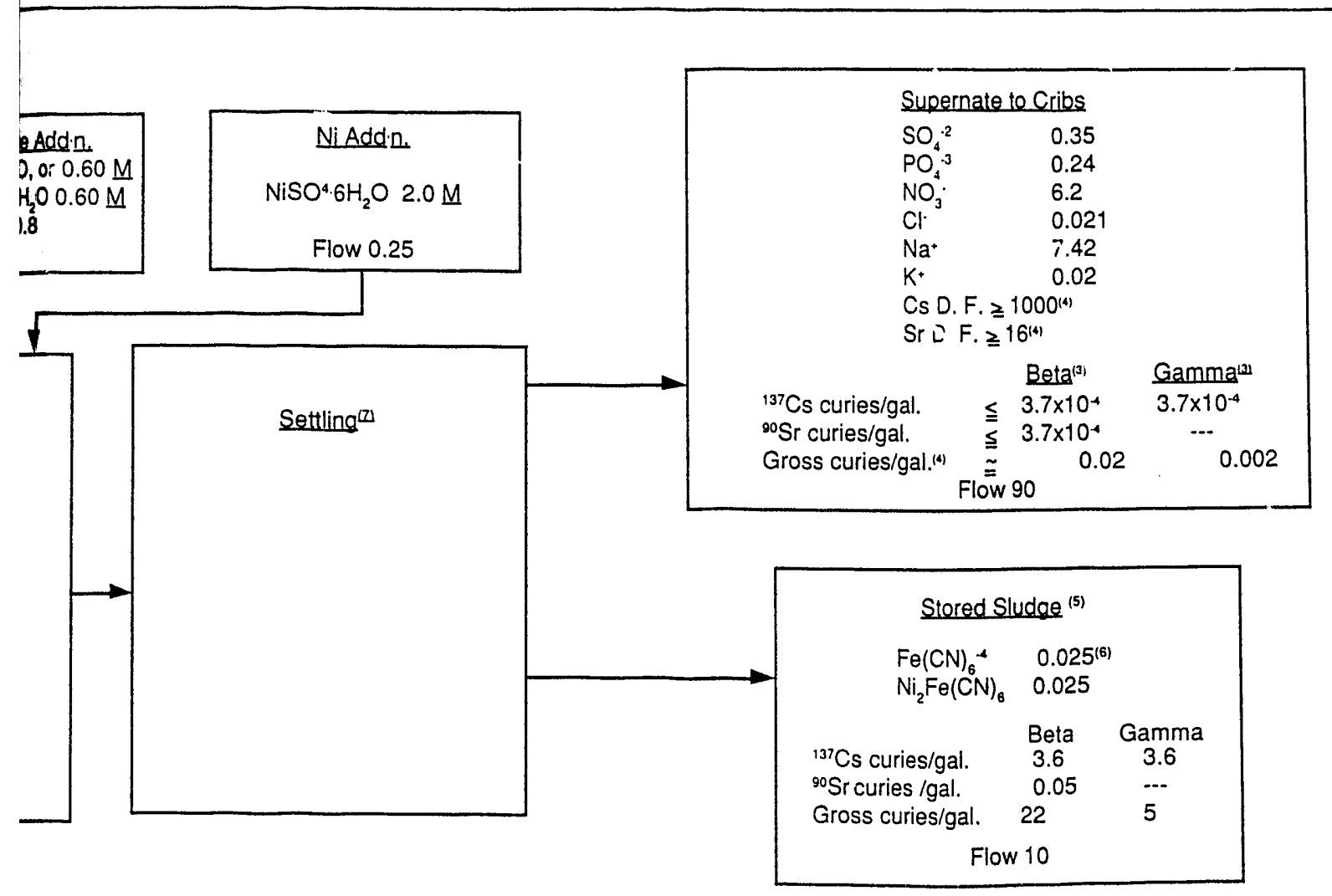

pH of approximately 10.5, the nitric acid flow shown above would be required to adjust the pH of the waste to approximately 9 .

: produced from $600 \mathrm{MWD} /$ ton uranium (2.4 megawatts/ton-250 day pile exposure assumed). Strontium and gross beta have received a D F of cussed in HW-31442 [Burns, Brandt, and Clifford (1954)].

addition to the small volume of NiFe $(\mathrm{CN})_{6}$ solids, a large amount of supernatant is present in the sludge volume shown.

sium and iron complexes are believed to be formed.

If plant practice these concentratic is may vary by a factor of 2 . However, such changes will not affect the relative volumes or the amounts of scavenger

R9108006.1P

\section{alized Concentrated RAW Supernatant From Underground Storage}


Table 3.1. Process History as Described by Abrams (1956)

Date

$\underline{1954}$

Sep 29 Started routine scavenging of dilute TBP waste solution. Flowsheet: $0.005 \mathrm{M}$ $\mathrm{K}_{4} \mathrm{Fe}(\mathrm{CN})_{6}$ and $0.005 \mathrm{M} \mathrm{NiSO}_{4}$ in the neutralized waste.

Nov 20 No waste produced. TBP Plant conversion to series operation.

\section{Event}

$\operatorname{Dec} 21$

$\underline{1955}$

Jan 13 Started batch operation in the 11-6 neutralizer tank due to poor strontium scavenging. Ferrocyanide added to acid waste, nickel sulfate to $11-6$ after neutralization.

Feb 1 Returned to continuous addition of $\mathrm{NiSO}_{4}$ during neutralization. There had been no improvement in the ${ }^{90} \mathrm{Sr}$ scavenging.

Feb 18 Erratic $\mathrm{pH}$ control. Checking neutralized waste with litmus.

Mar 1

Mar 1 Started evaporating neutralized waste to conserve waste storage space. $\mathrm{NiSO}_{4}$ added to waste after concentration.

Mar 18 Conducted plant tests (supplemental additions of $\mathrm{Ca}\left(\mathrm{NO}_{3}\right)_{2}$ to concentrated waste for Apr 8 improved ${ }^{90} \mathrm{Sr}$ scavenging). Improvement in DF by 3.0 to 4.0 , and by 6.0 when heated to $90^{\circ} \mathrm{C}$.

Mar 29 Started automatic control of $\mathrm{pH}$, waste and caustic addition rates. Set the $\mathrm{pH}$ at 9.3.

Apr 18 Use of commercial grade sodium ferrocyanide instead of potassium ferrocyanide was started. Savings in chemical costs of $\$ 11.00$ per ton $U$ processed were effected.

Apr 21 Routine addition of $\mathrm{Ca}\left(\mathrm{NO}_{3}\right)_{2}$ to $9-7$ tank. Marked improvement in ${ }^{137} \mathrm{Cs}$ and ${ }^{90} \mathrm{Sr}$ scavenging resulted.

May 3 Low $\mathrm{pH}$ values (6.7 to 7.8) in the concentrated waste. Adjusted $\mathrm{pH}$ setting to 10.0 to May 6 compensate for $\mathrm{Ca}\left(\mathrm{NO}_{3}\right)_{2}$ addition and concentration step which had lowered the $\mathrm{pH}$ about one unit. 
Table 3.1. (contd)

Date Event

May 20 Eliminated caustic ratio analyses of acid waste batch samples. Automatic control of the $\mathrm{pH}$ working efficiently.

Aug 12 Conducted plant-scale tests, using $\mathrm{Sr}\left(\mathrm{NO}_{3}\right)_{2}$ as a supplemental scavenging agent Aug 26 instead of $\mathrm{Ca}\left(\mathrm{NO}_{3}\right)_{2}$. Laboratory data had indicated a factor of two improvement in ${ }^{90} \mathrm{Sr}$ removal would result. Started one tank test using $\mathrm{Sr}\left(\mathrm{NO}_{3}\right)_{2}$ ad ditive. No concentration of waste. Flowsheet: $0.0025 \mathrm{M} \mathrm{Na}_{4} \mathrm{Fe}(\mathrm{CN})_{6}, 0.0025 \mathrm{M} \mathrm{NiSO}_{4}$, and $0.004 \mathrm{M} \mathrm{Sr}\left(\mathrm{NO}_{3}\right)_{2}$.

Sep 3 Supply of $\mathrm{Sr}\left(\mathrm{NO}_{3}\right)_{2}$ depleted. Resumed $\mathrm{Ca}\left(\mathrm{NO}_{3}\right)_{2}$ addition and waste concintration.

Nov 4 Started a three tank test using $\mathrm{Sr}\left(\mathrm{NO}_{3}\right)_{2}$ as a supplemental scavenging agent. Dilute neutralized waste routed to settling tanks.

Dec 9 Resumed concentration of waste and $\mathrm{Ca}\left(\mathrm{NO}_{3}\right)_{2}$ addition; due to delay in delivery of $\operatorname{Dec} 30 \mathrm{Sr}\left(\mathrm{NO}_{3}\right)_{2}$.

Dec 30 Again started $\mathrm{Sr}\left(\mathrm{NO}_{3}\right)_{2}$ treatment of waste, with no concentration.

$\underline{1956}$

Jan $3 \quad{ }^{137} \mathrm{Cs}$ first detected in the ground water under the 216-BY cribs.

Jan 6 Added $\mathrm{Na}_{3} \mathrm{PO}_{4}$ to scavenged waste (WR-002) to increase the $\mathrm{PO}_{4}$ concentration. Phosphate low due to system flushes.

Jan 17 Ali scavenged waste produced using $0.0025 \mathrm{M} \mathrm{Na}_{4} \mathrm{Fe}(\mathrm{CN})_{6}, 0.0025 \mathrm{M} \mathrm{NiSO}_{4}$, and Apr $30.004 \mathrm{M} \mathrm{Sr}\left(\mathrm{NO}_{3}\right)_{2}$ scavenging has been acceptable for cribbing.

Mar 5 Detected ${ }^{60} \mathrm{Co}$ in the ground water under the BY cavern. Studies are in progress to assure removal of this contaminant before future scavenged waste supernatant is released to ground.

May 5 On a test basis, cobalt sulfate is being added to the TBP Plant waste, to improve ${ }^{60} \mathrm{Co}$ scavenging by isotope dilution. Flowsheet: $0.0025 \mathrm{M} \mathrm{Na}_{4} \mathrm{Fe}(\mathrm{CN})_{6}, 0.0025 \mathrm{M} \mathrm{NiSO}_{4}$, $0.004 \mathrm{M} \mathrm{Sr}\left(\mathrm{NO}_{3}\right)_{2}$, and $0.00012 \mathrm{CoSO}_{4}$. 
summary when "in-tank" scavenging started and scavenging of the TBP Plant wastes was shut down. Sloat (1955) indicated that there was a difference in the waste types, but no mention of this difference is made by Abrams (1956)

Approximately $8.4 \cdot 10^{4} \mathrm{~m}^{3}\left(22 \cdot 10^{6}\right.$ gal $)$ of waste were scavenged and $6.1 \cdot 10^{4} \mathrm{~m}^{3}$ $\left(16 \cdot 10^{6} \mathrm{gal}\right.$ ) were sent to the cribs during the period from September 1954 to May 1956 (Abrams 1956). 


\subsection{Ferrocyanide Chemistry and Reactions}

\subsection{The Metal Cyanide Complexes}

Nearly all the d-transition metals form cyanide complexes, in a wide range of metal-ligand ratios and a variety of structures (configurations), which include linear, triangular, square, octahedral, and dodecahedral geometries. The hexacyano-iron complexes are probably the best known, having been studied for well over 200 years (American Cyanamid 1953). An assortment of structures were suggested over the years; but the octahedral configuration proposed by Werner and supported by Pauling has been accepted (Pauling 1939). The electronic structures have been described in detail by Chadwick and Sharpe (1966) and by Sharpe (1976). Most of the higher complexes are very stable with respect to dissociation, and those of iron are no exception. The triple-bonded $\mathrm{CN}^{-}$is covalently bonded to the metal, normally through the $\mathrm{C}$ atom. Back donation of electrons strengthens the $\mathrm{M}-\mathrm{C}(\mathrm{M}=$ metal) bond but slightly weakens the $\mathrm{C}-\mathrm{N}$ bond. Sillen and Martell (1964) list stability constants for the $\mathrm{CN}^{-}$complexes of most metals.

In these complexes an electron is easily transferred between $\mathrm{Fe}(\mathrm{II})$ and $\mathrm{Fe}(\mathrm{III})$. The equilibria

$$
\left[\mathrm{Fe}(\mathrm{CN})_{6}\right]^{3-}+e^{-}=\left[\mathrm{Fe}(\mathrm{CN})_{6}\right]^{4-} \quad E^{0}=+0.36 \mathrm{~V}
$$

and

$$
F e^{2+}=e^{-}+F e^{3+} \quad E^{0}=-0.77 V
$$

combine to indicate that the ferrocyanide ${ }^{(a)}$ complex is the stronger of the two hexacyano-iron complexes. Dissociation constants for the two hexacyano complexes are given by Sharpe (1976) as $2.5 \cdot 10^{-36}$ and $2.5 \cdot 10^{-44}$ for the ferro and ferri complexes, respectively. Other sources indicate higher dissociation constants, but the order is the same. However, hydrolysis and the insolubility of ferric hydroxide change the relative stabilities with respect to dissociation with the result that the ferrocyanides are the more stable. Thus, ferrocyanides are considered nontoxic while ferricyanides may dissociate slightly in aqueous solution to form $\mathrm{HCN}$ or $\mathrm{CN}^{-}$ion, both of which lead to the toxicity for the ferricyanide.

The present discussion is concerned primarily with the ferrocyanides and emphasizes the solid transition metal salts involving nickel.

Pyrolysis of the sodium and potassium ferrocyanide salts at $400^{\circ} \mathrm{C}$, or slightly higher produces a mixture of products including the cyanate salt, nitrogen, carbon, and, at high temperatures,

(a) The proper nomenclature for the ferro- and ferricyanides is hexacyanoferrate(II) and hexacyanoferrate(III), respectively. However, in this paper the traditional names are used. 
some free alkali metal. Pyrolysis in oxygen gives similar products with the additional product sodium carbonate (American Cyanamid 1953). No information has been found for the thermal decomposition of alkali metal nickel ferrocyanides, but Wirta and Koski (1957) found the thermal decomposition of cesium zinc ferrocyanide to be exothermic. Experiments at PNL using differential scanning calorimetry (DSC) and thermal gravimetric analyses (TGA) suggest that complete oxidation to nitrogen and $\mathrm{CO}_{2}$ or carbonates may occur by about $500^{\circ} \mathrm{C}$ although the products have not been conifirmed. The DSC tests on cesium nickel ferrocyanide (Figure 4.2) indicated a reaction starting at about $230^{\circ} \mathrm{C}$ to $260^{\circ} \mathrm{C}$, with a maximum in the exotherm at about $305^{\circ} \mathrm{C}$ to $330^{\circ} \mathrm{C}$ (Burger and Scheele 1990). Incomplete data for the sodium nickel ferrocyanides and ferricyanides suggest that the reaction may start at a temperature below $200^{\circ} \mathrm{C}$. Hepworth, McClanahan, and Moore (1957) observed decomposition beginning at $480^{\circ} \mathrm{C}$ for the analogous dicesium zinc compound.

Many single and double salts of hydroferrocyanic acid are known. Because of the chemical stability and low solubility of many of the salts, they have been developed for use as pigments.

\subsection{Probable Tank Precipitates}

If potassium ferrocyanide is added to a solution of a zinc salt, $\mathrm{Zn}_{2} \mathrm{Fe}(\mathrm{CN})_{6}$ forms. However, as the equivalence point is reached, a mixed salt containing potassium is formed. This appears to be the general case, and simple stoichiometric compounds are seldom formed. That this is especially true for the nickel salts is evident from the review of Loos-Neskovic et al. $(1984,1989)$. Thus, the composition of the precipitates depends on the relative solution concentrations, the order of addition of the reagents, probably the $\mathrm{pH}$, the temperature, and, of course, the individual solubilities. For the alkali metal nickel ferrocyanides, the order of decreasing solubility and decreasing apparent reactivity is increasing atomic number. The solubility of di-nickel ferrocyanide is reported to be $2.0 \cdot 10^{-5} \mathrm{~g} \mathrm{Ni} / \mathrm{L}$ (Tananaev, Gluchkova, and Seifer 1956). No information has been found for the sodium nickel salts. A large amount of work has been reported which demonstrates the ability of solid nickel ferrocyanide complexes to remove cesium from solution by ion exchange (Loos-Neskovic et al. 1989).

The crystal structure of the nickel ferrocyanide salts is generally face centered cubic (Sharpe 1976; Ceranic 1978) and for $\mathrm{M}_{2} \mathrm{NiFe}(\mathrm{CN})_{6}(\mathrm{M}=$ alkali metal) the simple cell would have iron and nickel atoms at alternate corners with the $\mathrm{CN}$ ligand between them, and an alkali metal ion in the center. Vacancies lead to non-stoichiometry. Different alkdi/nickel/iron ratios can also distort the lattice to a tetragonal form.

Considering the above factors, the precipitates that originally formed in the waste treatment process would have logically included $\mathrm{Na}_{2} \mathrm{NiFe}(\mathrm{CN})_{6}, \mathrm{Ni}_{2} \mathrm{Fe}(\mathrm{CN})_{6}$, small amounts of $\mathrm{K}_{2} \mathrm{NiFe}(\mathrm{CN})_{6}$ 
and $\mathrm{Cs}_{2} \mathrm{NiFe}(\mathrm{CN})_{6}$, and large amounts of a mixed salt, $\mathrm{Na}_{x} \mathrm{Ni}_{y}\left[\mathrm{Fe}(\mathrm{CN})_{6}\right]_{z}$ where $4 z=x+2 y .{ }^{(a)}$ The preparations that have been examined have contained 2 to 4 moles of water per moie of ferrocyanide.

The prediction that sodium nickel ferrocyanide is the principal precipitated form is due to the fact that solutions to which the $0.005 \underline{\mathrm{M}}$ nickel and ferrocyanide ions were added were from 3 to $6 \underline{\mathrm{M}}$ in sodium nitrate/nitrite. There are no solubility data nor sample analyses to confirm this hypothesis. At:empts have been made to prepare these various forms in PNL laboratories, and a variety of tests have been carried out on the products.

The solid nickel complexes are inert to most reagents. Sulfuric acid heated to fuming readily dissolves the solids. A large excess of EDTA will also dissolve the compounds. For metal analysis, the most convenient approach is to heat the samples in air it $800^{\circ} \mathrm{C}$ ar $\mathrm{d}$ dissolve the resulting oxides in $\mathrm{HCl}$.

The precipitates are very fine and nearly impossible to filter. Washing with water tends to produce colloids. The precipitates formed may occlude salts present in the solution.

\subsection{Possible Reactions in Waste Tanks}

Cyanides are strong reductants and are known to react explosively with nitrates, nitrites, chromates and other strong oxidants. Hepworth, McClanahan, and Moore (1957) described explosive behavior of cesium zinc ferrocyanide when attempts were made to dry samples which were wet with nitrate solutions. Other observations placed the threshold temperature of the material in contact with sodium nitrate at $375^{\circ} \mathrm{C}$ (Cooper 1957). If solid nitrates were heated with the dry compound, explosions accompanied by dense white fumes were observed.

The explosive reaction of molten sodium nitrate and sodium cyanide is noted by Sax (1957) and by the National Board of Fire Underwriters (1950). An Austrian explosives patent is based on mixtures of nitrites and cyanides or ferrocyanides (Eiter, Vogl, and Michl 1954).

Over the past three years numerous explosive tests have been carried out using milligram quantities of cyanide compounds including those expected to exist in Hanford process tanks. These tests along with scanning calorimetry and gravimetry measurements, while not defining the actual reactions which take place, do provide much information on the nature of these reactions. Preliminary data have been presented in interim reports (Burger and Scheele 1988; 1990).

The energetics of the oxidation of these compounds can be estimated from the enthalpies of formation of the reactants and products. For the nickel hexacyanoferrates no data were found. Based on both enthalpies and free energies of formation of a variety of complex cyanides

(a) A more realistic formulation for the ferrocyanide precipitate is $[\mathrm{Na}(\mathrm{K}, \mathrm{Rb}, \mathrm{Cs})]_{\mathrm{x}} \mathrm{Ni}_{\mathrm{y}}$ $\left[\mathrm{Fe}(\mathrm{CN})_{6}\right]_{2}$. 
Table 4.1. Calculated Energy Release for Oxidation of Some Cyanides and Ferrocyanides

\begin{tabular}{|c|c|c|c|}
\hline Compound & Oxidant & Products $^{\mathrm{a}}$ & Energy, $\mathrm{kJ}$ \\
\hline $\mathrm{Na}_{2} \mathrm{NiFe}(\mathrm{CN})_{6}$ & $\mathrm{NaNO}_{3}$ & $\mathrm{Na}_{2} \mathrm{CO}_{3}, \mathrm{CO}_{2}, \mathrm{~N}_{2}$ & -3012 \\
\hline$n$ & " & $\mathrm{Na}_{2} \mathrm{O}, \mathrm{CO}_{2}, \mathrm{~N}_{2}$ & -1722 \\
\hline$n$ & $n$ & $\mathrm{Na}_{2} \mathrm{O}, \mathrm{CO}, \mathrm{N}_{2}$ & -240 \\
\hline$n$ & $n$ & $\mathrm{Na}_{2} \mathrm{CO}_{3}, \mathrm{Na}_{2} \mathrm{O}, \mathrm{NO}$ & +230 \\
\hline$n$ & $\mathrm{NaNO}_{2}$ & $\mathrm{Na}_{2} \mathrm{CO}_{3}, \mathrm{~N}_{2}$ & -3708 \\
\hline $\mathrm{Ni}_{2} \mathrm{Fe}(\mathrm{CN})_{6}$ & $\mathrm{NaNO}_{3}$ & $\mathrm{Na}_{2} \mathrm{CO}_{3}, \mathrm{CO}_{2}, \mathrm{~N}_{2}$ & -2880 \\
\hline$"$ & $\mathrm{NaNO}_{2}$ & $\mathrm{Na}_{2} \mathrm{CO}_{3}, \mathrm{CO}_{2}, \mathrm{~N}_{2}$ & -3480 \\
\hline $\mathrm{NaCN}$ & $\mathrm{NaNO}_{3}$ & $\mathrm{Na}_{2} \mathrm{CO}_{3}, \mathrm{~N}_{2}$ & -3450 \\
\hline
\end{tabular}

(a) Other products are $\mathrm{FeO}$ and $\mathrm{NiO}$

(Wagman et al. 1982; Barin 1989) values of $\Delta \mathrm{H}_{\mathrm{f}}=+200 \mathrm{~kJ}$ for di-nickel ferrocyanide and zero for the sodium nickel ferrocyanide were assumed. These values are uncertain to at least $200 \mathrm{~kJ}$.

Six moles of nitrate or 10 moles of nitrite are required for the complete oxidation of one mole of ferrocyanide. The products of the reaction with either nitrate or nitrite salts may include $\mathrm{N}_{2}, \mathrm{CO}_{2}, \mathrm{CO}, \mathrm{NO}, \mathrm{Na}_{2} \mathrm{O}, \mathrm{NaOH}, \mathrm{Na}_{2} \mathrm{CO}_{3}, \mathrm{NiO}, \mathrm{FeO}$, and traces of carbon and other compounds. The product $\mathrm{NaOH}$ assumes some water is present. The calculated energy release is highly sensitive to the products formed, as the data in Tahle 4.1 show. If a sizable fraction of the carbongoes to $\mathrm{CO}$, or if appreciable oxides of nitrogen form, the energy is greatly reduced. On the other hand, a change from one ferrocyanide salt to another makes a much smaller change.

Some comment regarding the sodium salt is necessary. On the basis of stability, the carbonate product should predominate up to about $1827^{\circ} \mathrm{C}$ at which point decomposition to the oxide becomes appreciable. Above about $1927^{\circ} \mathrm{C}$ the decomposition of the oxide itself becomes important. However, if water vapor is present, sodium hydroxide becomes the most stable sodium form above about $1727^{\circ} \mathrm{C}$. At this temperature, sodium hydroxide is in the vapor form. Thus, without knowing the final temperature and the components in the reactive mixture, a single reaction cannot be specified. Secondly, there is no reason to expect that equilibrium is reached aniong the products formed.

A reasonable value for the maximum energy released is about $3300 \mathrm{~kJ}$ per mole of ferrocyanide or $3.7 \mathrm{~kJ}$ per gram of a stoichiometric mixture of sodium nickel ferrocyanide and a 50/50 mole percent mix of sodium nitrate/sodium nitrite. 


\subsection{Reactivity Measurements}

Chemical reactivity measurements made at PNL have ircluded small-scale explosive testing and thermal analysis of ferrocyanide-nitrate/nitrite mixtures. In addition, evaluation tests on a near-stoichiometric mix of cesium nickel ferrocyanide and $50-50 \mathrm{~mol} \%$ sodium nitrate-nitrite were made by the Los Alamos National Laboratory (LANL) (Cady et al. 1989).

4.4.1 Time-To-Explosion Tests. Time-to-explosion (TTX) data were obtained at PNL by inserting a sample of cyanide compound mixed with oxidant in a heated metal block. The 40- to 100 -mg samples were contained in 5-mm-dia. thin wall ( $\mathrm{nmr}$ ) tubes. The times and nature of explosion or other reaction were recorded. This test is similar to the standard Henkin test (Henkin and McGill 1952) used in the evaluation of explosives. Figure 4.1 shows a typical set of data. Table 4.2 lists pertinent data obtained for these tests. The following comments summarize the results:

- Sodium nickel ferrocyanides and ferricyanides or ferrocyanides with a high nickel content are more reactive that cesium nickel ferrocyanide.

- Reactions with nitrites are more vigorous than with nitrates alone.

- The brisance (shattering effect) increases with nitrite concentration, temperature, and quantity of material, the reaction often pulverizing the tube in the resulting sharp explosion.

- Heating at temperatures below the critical temperature, $T_{0}$ often produces some NO and/or $\mathrm{NO}_{2}$ gas in a mild reaction. If the mixture is then placed in a block at high temperature an explosion sometimes still occurs.

- The maximum explosive behavior is probably with near stoichiometric mixes, but large excesses of either the ferrocyanide or the oxidant may still produce explosions. The experimental dilution limits have not yet been determined.

- The addition of sodium EDTA increased the explosivity as does nickel hydroxide and to a lesser extent ferric hydroxide. Small amounts of sodium hydroxide or tributyl phosphate (TBP) had a negligible effect.

- Attempts to obtain kinetic information by plotting the log of the reaction time, with a correction for temperature lag, vs $1 / \mathrm{T}$ were inconclusive but do suggest a mechanism change in the vicinity of $300^{\circ} \mathrm{C}$.

- The explosive tests are not always reproducible with respect to either time or temperature. This is characteristic of explosive reactions.

- The violence of the reactions observed leaves no doubt as to the explosive behavior if a mix of ferrocyanides and nitrate or nitrite salts is heated rapidly. However, it is possible that slow heating may produce slower and less exothermic reactions. 


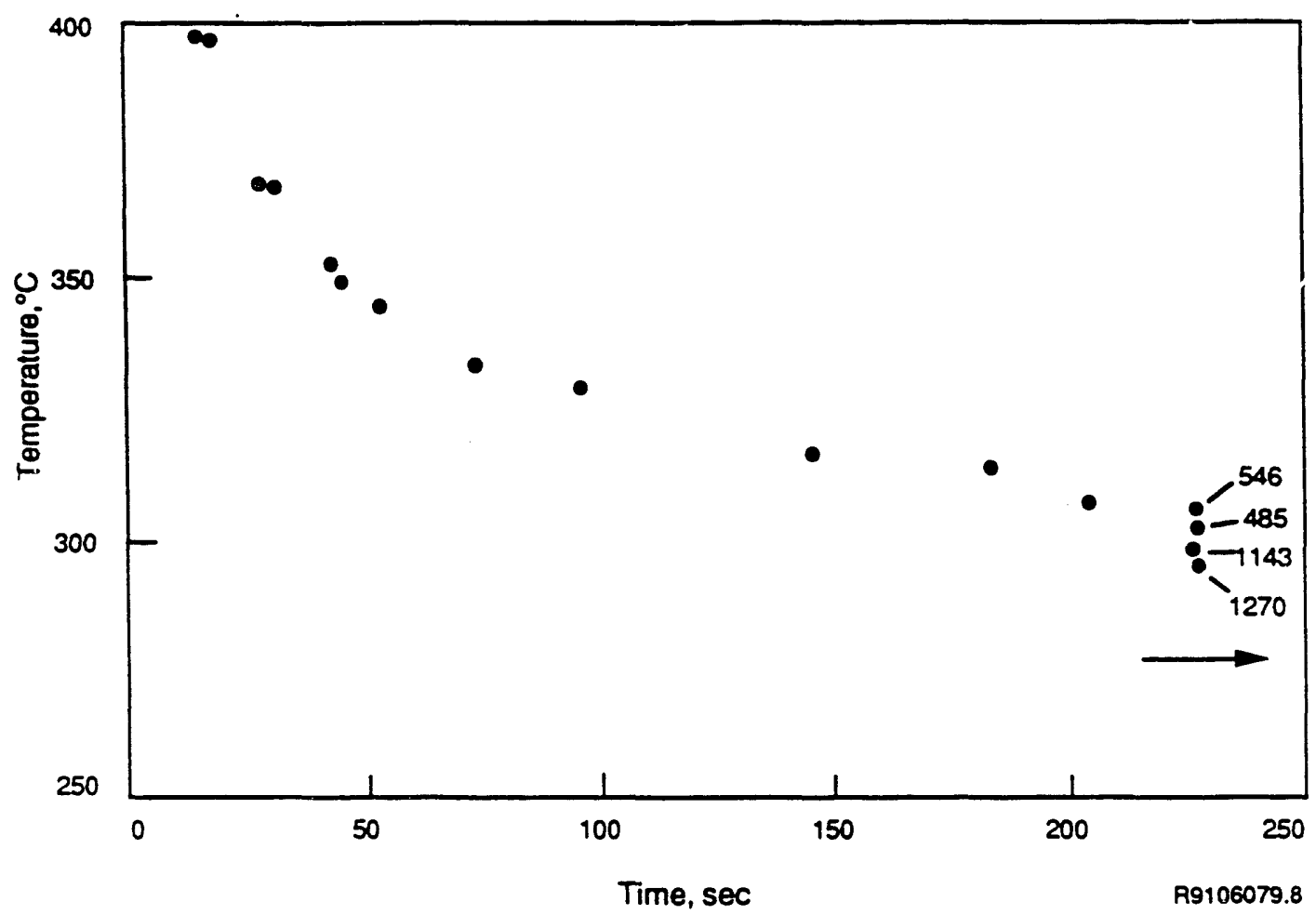

Figure 4.1. A Typical Time-to-Explosion Plot. This example is for $50 \% \mathrm{Cs}_{2} \mathrm{NiFe}(\mathrm{CN})_{6}$ with $50 \%$ of a Mixture $65 \% \mathrm{NaNO}_{3}$ and $35 \% \mathrm{KNO}_{2}$

4.4.2 Thermal Measurements. Thermal measurements using both differential scanning calorimetry (DSC), and scanning thermal gravimetry (STG) have been made on the cyanide compounds in air alone, and with mixtures of nitrates and nitrites. Typical results are shown in Figures 4.2 through 4.6. Figures 4.2 and 4.3 are for cesium nickel ferrocyanide on which consicierable work has been done. Chemical analysis indicates that this material is close to stoichiometric $\left[\mathrm{Cs}_{2} \mathrm{NiFe}(\mathrm{CN})_{6}\right]$ in composition and has reproducible properties. The potassium salt, Figure 4.4, may also be close to stoichiometric but analyses have not been made. In Figures 4.5 and 4.6, thermal analysis results are shown for sodium nickel ferrocyanide and sodium nickel ferricyanide, respectively. Compounds made using typical preparative schemes have a variable nickel-to-sodium ratio. Salient features of the DSC plots are the temperature at the beginning of the exothermic reaction, the temperature at the exotherm ma'timum, and the general complexity (multiple peaks) of the exotherms. The latter suggests that a complex (stepwise) reaction may be occurring.

The enthalpies for the reactions may be computed from the areas of the exothermic peaks and serve a comparative purpose, but are generally not quantitatively reliable. 
Table 4.2. Time-to-Explosion Data for Small Samples

\begin{tabular}{c} 
Compound \\
\hline $\mathrm{Cs}_{2} \mathrm{NiFe}(\mathrm{CN})_{6}$ \\
$"$ \\
$"$
\end{tabular}

\begin{tabular}{c} 
Oxidant \\
\hline$(\mathrm{Na}, \mathrm{K}) \mathrm{NO}_{3}$ \\
$(\mathrm{Na}, \mathrm{K}) \mathrm{NO}_{2}$ \\
$\mathrm{Na}\left(\mathrm{NO}_{3}, \mathrm{NO}_{2}\right)$ \\
$"+5 \% \mathrm{Ni}(\mathrm{OH})_{2}$ \\
$"+5 \% \mathrm{EDTA}$ \\
$\mathrm{Na}\left(\mathrm{NO}_{3}, \mathrm{NO}_{2}\right.$ \\
$"$ \\
$"$ \\
$"$
\end{tabular}

$\mathrm{t}$ sec at $360^{\circ} \mathrm{C}$
15
33
50
18
8
240
27
10
13

Tc (estimated), ${ }^{\circ} \mathrm{C}$
$310 \pm 10$
$300 \pm 5$
$340 \pm 10$
$300 \pm 5$
$280 \pm 5$
$350 \pm 20$
$330 \pm 10$
$280 \pm 10$
$300 \pm 10$

(a) The $\mathrm{Na} / \mathrm{Ni}$ ratio is uncertain

(b) Although high in Ni the compound still contains some alkali metal ions

(c) ferricyanide compound.

The thermal anaiysis work is ongoing but results to date can be summarized as follows:

- The nickel complexes react at a lower temperature than alkali metal cyanides or alkali ferrocyanides.

- The minimum temperature at which an exotherm is first noted is in the vicinity of $220^{\circ} \mathrm{C}$. The temperature at which the exotherm is a maximum ranges from about $280^{\circ} \mathrm{C}$ to $320^{\circ} \mathrm{C}$.

- The reaction with a typical mixed nitrate/nitrite salt is complex and shows multiple exothermic neaks. The reaction with nitrate salts varies somewhat with the cation and may show single or multiple peaks. The reaction with nitrites is much faster and normally shows a single sharp peak at about $260^{\circ} \mathrm{C}$ to $300^{\circ} \mathrm{C}$.

- Some evidence of a beginning reaction at lower temperatures, between $180^{\circ} \mathrm{C}$ and $230^{\circ} \mathrm{C}$, is obscured by endotherms characteristic of the oxidant.

- No information exists at present regarding the specific reaction steps responsible for the different exotherms. 


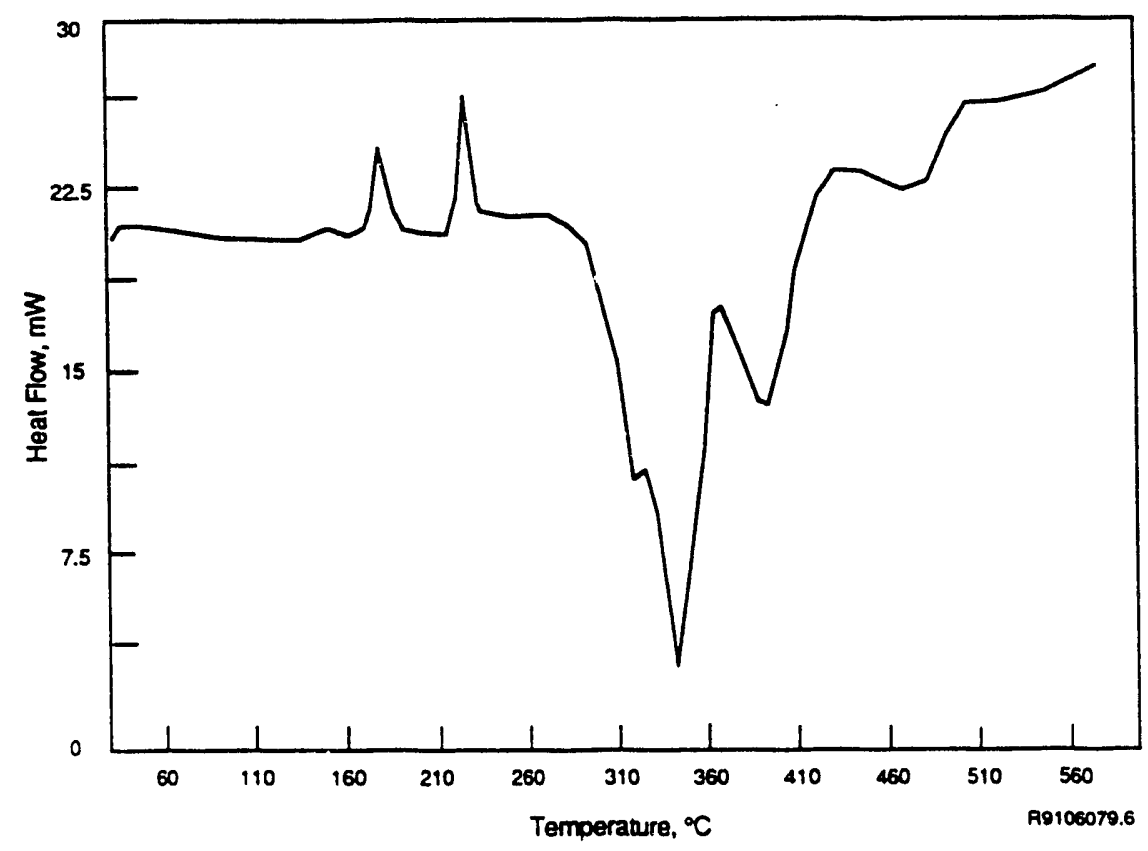

Figure 4.2. Results from a Differential Scanning Calorimeter Experiment Using $\mathrm{Cs}_{2} \mathrm{NiFe}(\mathrm{CN})_{6}+$ Stoichiometric $50 \mathrm{~mol} \% \mathrm{NaNO}_{3} / 50 \mathrm{~mol} \% \mathrm{NaNO}_{2}$

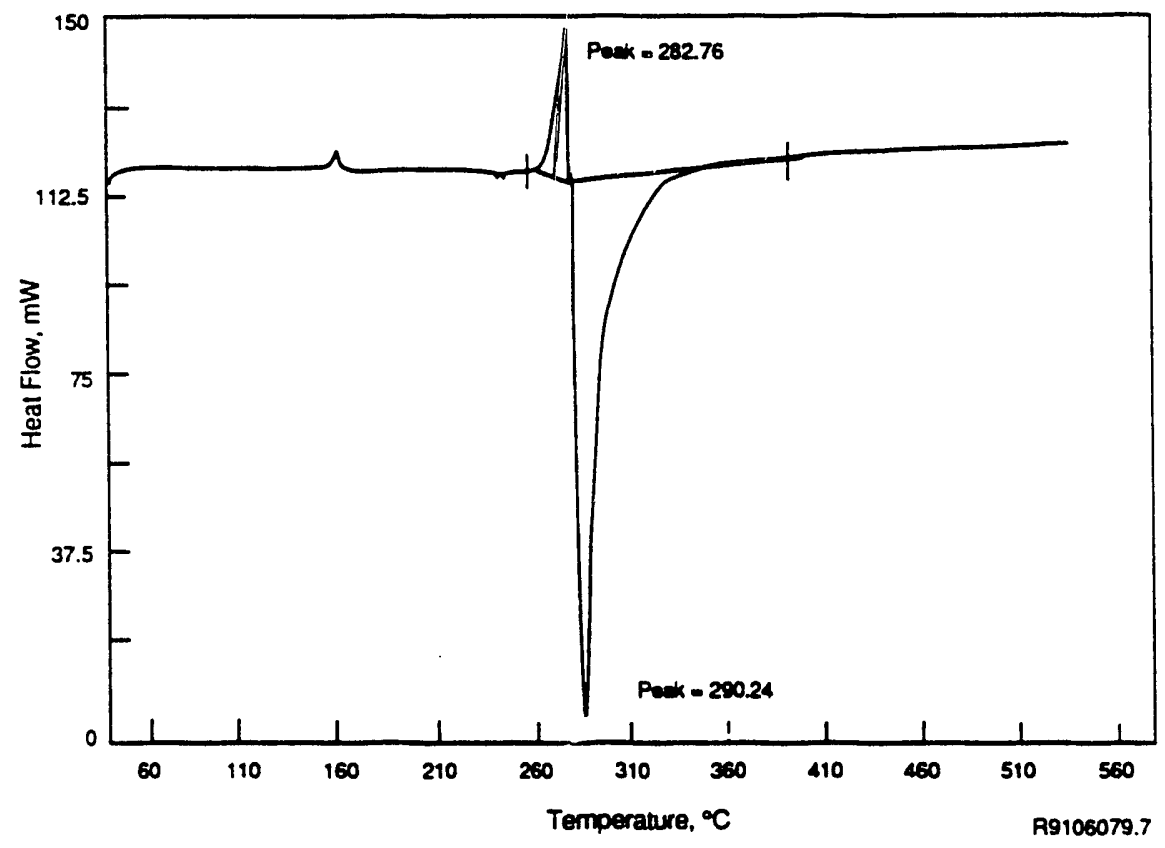

Figure 4.3. Results from a Differential Scanning Calorimeter Experiment Using $\mathrm{Cs}_{2} \mathrm{NiFe}(\mathrm{CN})_{6}+\mathrm{NaNO}_{2}$ 


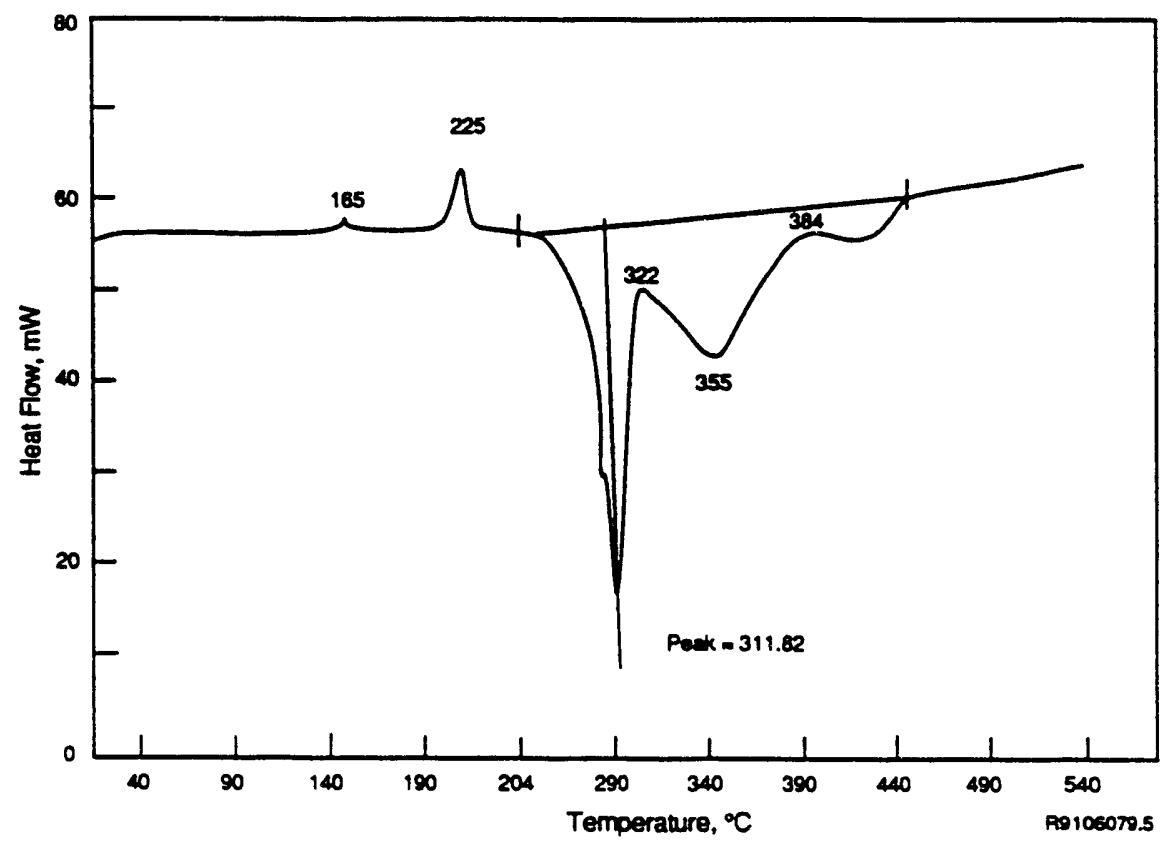

Figure 4.4. Results from a Differential Scanning Calorimeter Experiment Using $\mathrm{K} 2 \mathrm{NiFe}(\mathrm{CN})_{6}+50 \mathrm{~mol} \% \mathrm{NaNO}_{3} \mathrm{NaNO}_{2}$

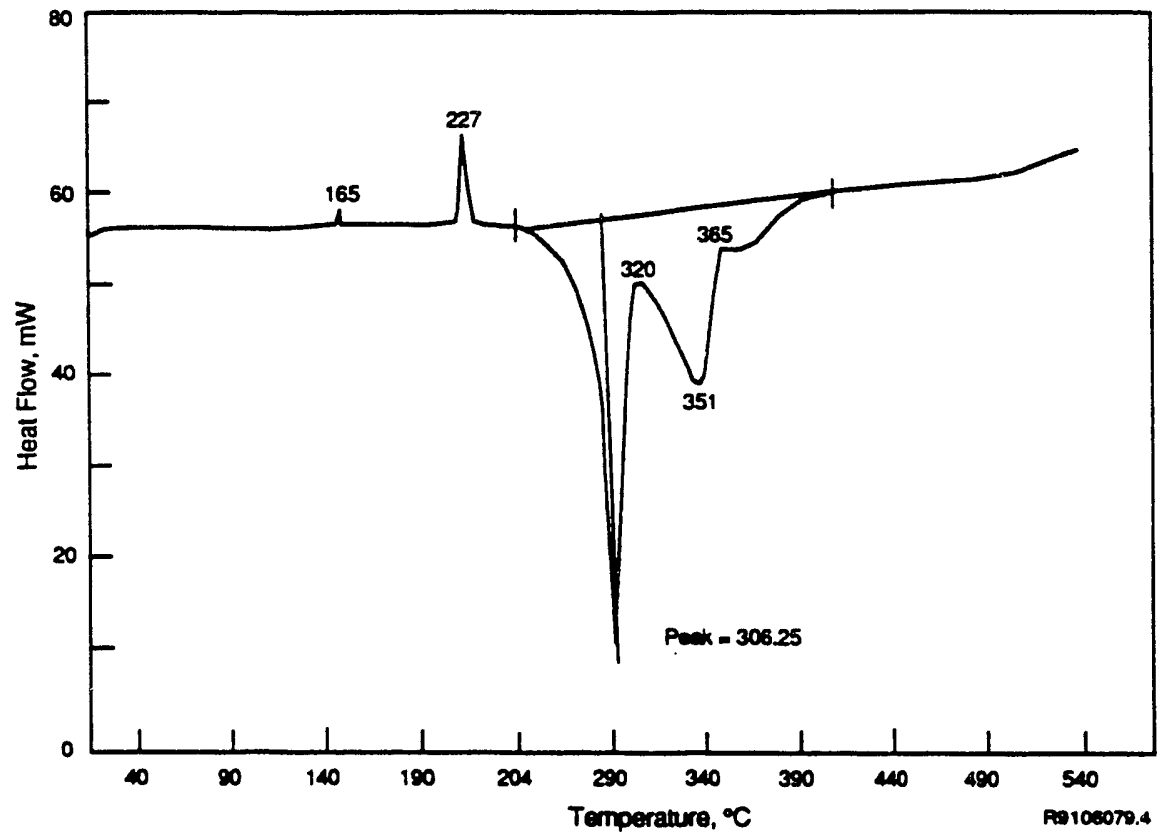

Figure 4.5. Results from a Differential Scanning Calorimeter Experiment Using $\mathrm{Na}_{2} \mathrm{NiFe}(\mathrm{CN})_{6}$ and $50 \mathrm{~mol} \% \mathrm{NaNO}_{3} / \mathrm{NaNO}_{2}$ 


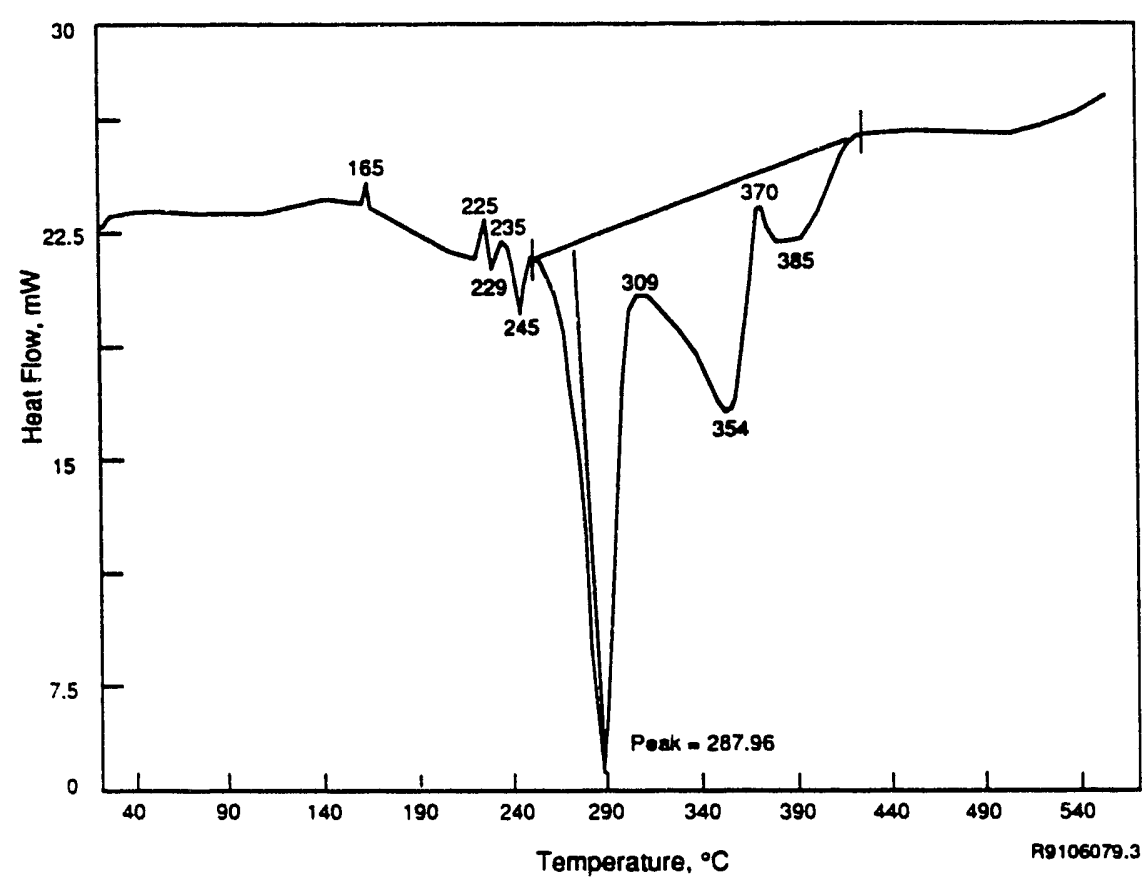

Figure 4.6. Results from a Differential Scanning Calorimeter Experiment Using $\mathrm{NaNiFe}(\mathrm{CN})_{6}$ and $50 \mathrm{~mol} \% \mathrm{NaNO}_{3} / \mathrm{NaNO}_{2}$

The complex structure of the DSC thermograms implies that the oxidation reaction is not simple. Some knowledge of the reaction mechanisms and the kinetic parameters of significant steps is necessary before the explosive reactions can be understood. Several experiments are underway to provide some of this information. The effect of changing the heating rate on the DSC data is illustrated in Figure 4.7. Using the method of Kissinger (1957), the activation energy for the reaction can be calculated from the position of the maximum energy release as a function of heating rate. For the reaction between $\mathrm{Cs}_{2} \mathrm{NiFe}(\mathrm{CN})_{6}$ and $\mathrm{NaNO}_{3}$, the activation energy is 132 $\mathrm{kJ} / \mathrm{mol}$. Since the reaction is complex, the empirical nature of this result must be emphasized.

Figure 4.8 is a typical STG plot. After the initial weight loss due to water, two major mass losses along with two or more smaller losses are suggested.

Data obtained at Los Alamos ${ }^{(a)}$ on a mixture of cesium nickel ferrocyanide and sodium nitrate/nitrite generally support the above reactivity conclusions. In addition, it was found that the initiation of a reaction between $\mathrm{Cs}_{2} \mathrm{NiFe}(\mathrm{CN})_{6}$ and sodium nitrate/nitrite was insensitive to shock, friction, or electric spark.

4.4.3 Catalysts and Initiators. Explosive reactions are often influenced by catalysts. A few potential catalysts have been tested at PNL. The choice was governed by the materials which

(a) Project repon prepared for PNL by H. H. Cady et al. 


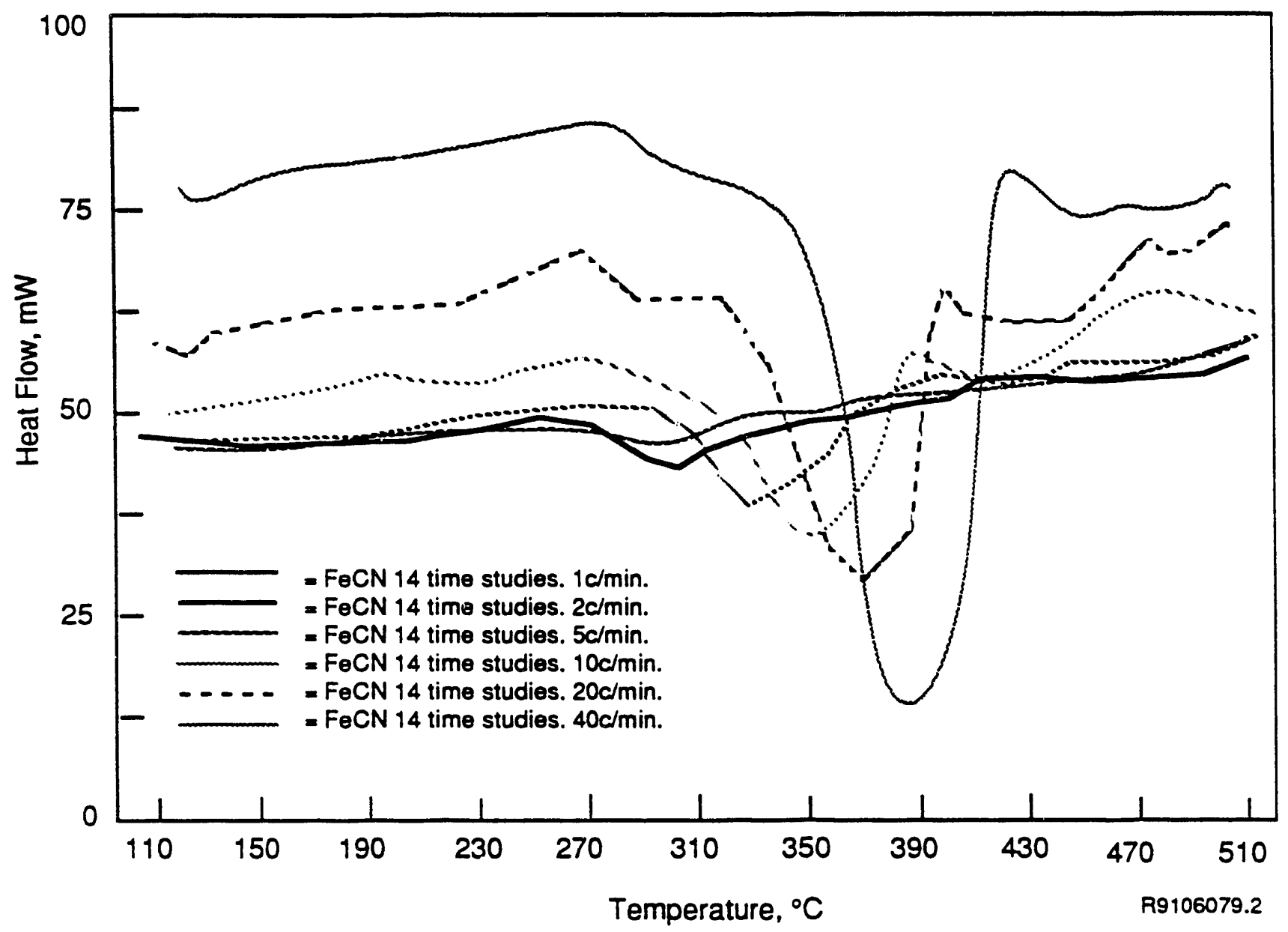

Figure 4.7. Results from Differential Scanning Calorimeter Experiments Using $\mathrm{Cs}_{2} \mathrm{NiFe}(\mathrm{CN})_{6}[\mathrm{FeCN}]$ and $50 \mathrm{~mol} \%\left[\mathrm{NaNO}_{3} / \mathrm{NaNO}_{2}\right.$ at Different Heating Rates

might be expected to be present in the waste tanks. The TTX tests and DSC tests were made with $5 \% \therefore \mathrm{Ni}(\mathrm{OH})_{2}, \mathrm{FeO}(\mathrm{OH}), \mathrm{NaOH}, \mathrm{TBP}$, and $\mathrm{Na}_{4}$ EDTA. The latter two compounds might be expected to act as initiators by reacting independently with the oxidants. The reactivity was markedly increased by the addition of nickel and EDTA compounds, and slightly by the iron compound. Further tests are being performed.

4.4.4 Diluents. Diluents in the reaction mix are expected to be extremely important. They may change the thermal conductivity of the mixture, thus influencing the propagation of the reaction; they may change the rates of bi-molecular steps; and most importantly, they introduce a heat 


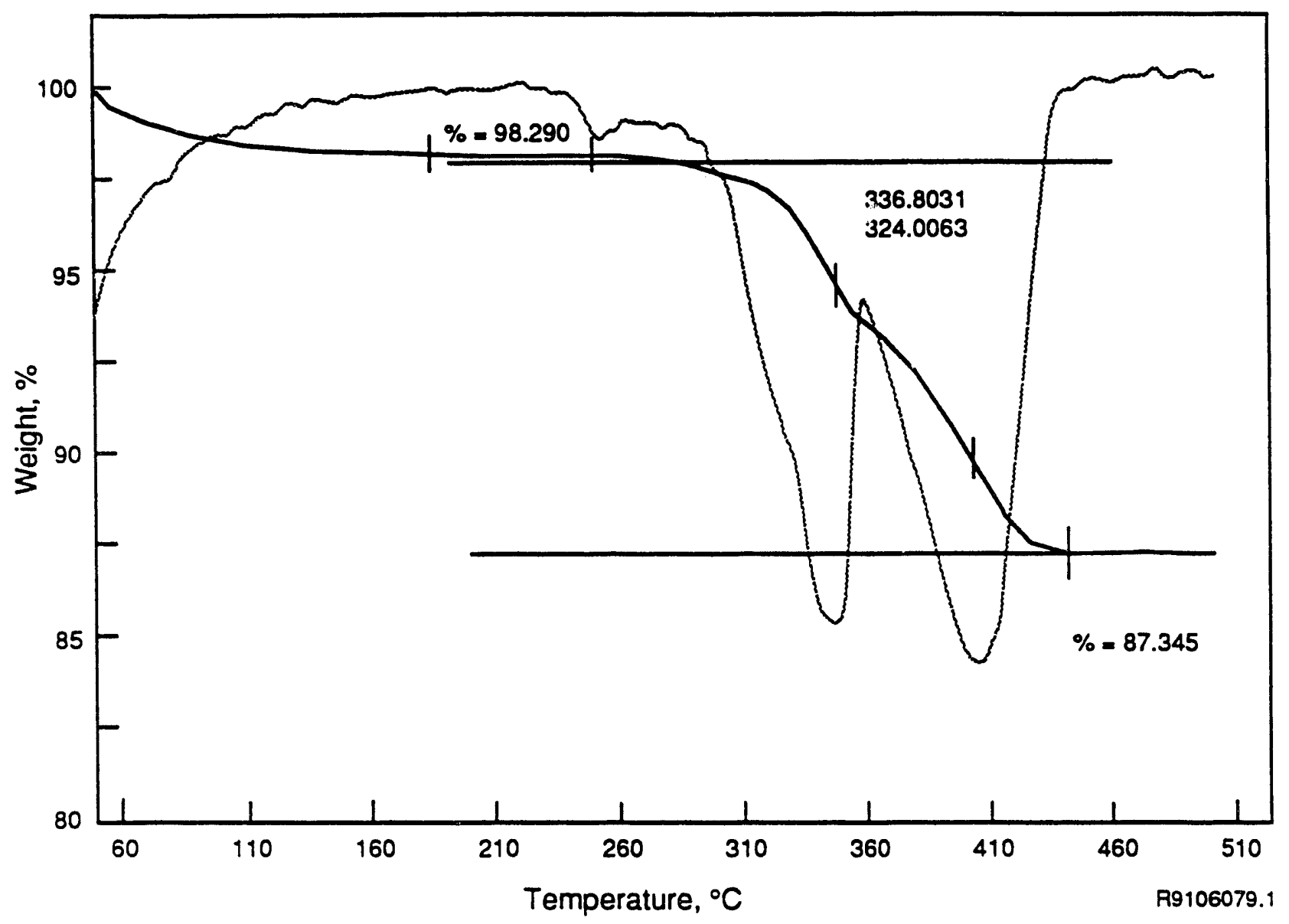

Figure 4.8. Results from a Scanning Thermogravimetric Experiment Using $\mathrm{Cs}_{2} \mathrm{NiFe}(\mathrm{CN})_{6}$ and $50 \% \mathrm{NaNO}_{3} / \mathrm{NaNO}_{2}$. The curve starting at $-93 \%$ is the first derivative of the other curve.

capacity that will control the temperature rise during an adiabatic process. Diluents likely to be present in the pertinent waste tanks include water, excess sodium nitrate and nitrite, aluminates, and a variable mix of lesser components such as silicates, sulfates, phosphates, and carbonates, and metal ions such as iron and bismuth.

Using heat capacity data and an assumption that the oxidation reaction is $80 \%$ efficient, the quantities of water, excess sodium nitrate, and a model diluent, sodium aluminate, that would prevent propagation of the reaction were calculated. These data are presented in Table 4.3. 
Table 4.3. Quantity of Diluent Required to Prevent Propagation of Ferrocyanide Oxidation (g diluent/g ferrocyanide) ${ }^{(a)}$

Reaction Temperature, ${ }^{\circ} \mathrm{C}$

$\Delta \mathrm{H}(80 \%$ of Theoretical), $\mathrm{kJ}$

$\mathrm{H}_{2} \mathrm{O}$

$\mathrm{NaNO}_{3}$

$\mathrm{NaAlO}_{2}$
Mass of Diluent Required, $g$

\begin{tabular}{ccc}
\hline $307^{(b)}$ & 250 & 200 \\
7966 & 8071 & 8146 \\
\hline $2.7(2.4)$ & $2.9(2.59)$ & $3.0(2.7)$ \\
$11.8(10.5)$ & $16.8(14.9)$ & $23.7(21.3)$ \\
$27.9(24.6)$ & $38.5(34.3)$ & $60.8(54.5)$
\end{tabular}

a) Reaction mix is $1.0 \mathrm{~g} \mathrm{Na}_{2} \mathrm{NiFe}(\mathrm{CN})_{6}+1.61 \mathrm{~g} \mathrm{NaNO}_{3}$. Values in ( ) assume each ferrocyanide molecule retains 4 molecules of water.

b) Calculation at $307^{\circ} \mathrm{C}$ assumes that runaway reaction requires melting of $\mathrm{NaNO}_{3}$. Heat of fusion of $\mathrm{NaNO}_{3}$ is not included in calculations at other temperatures.

Water is the best diluent because its vaporization enthalpy is large. While free water is easily lost, chemically bound water, such as in hydrates or in zeolytic materials, may remain until temperatures of $150^{\circ} \mathrm{C}$ to $200^{\circ} \mathrm{C}$ are attained. The enthalpy of fusicn of sodium nitrate aids in preventing a temperature rise in the vicinity of $300^{\circ} \mathrm{C}$. A thermal runaway reaction is precluded if sufficient diluent is present.

In these simplified models, all solid state transitions, including the decomposition of hydrates, were ignored. The latter was approximated in the water vaporization term.

Results from the TTX tests indicate that explosions occur with wide variations in the ferrocyanide-oxidant ratio, but the limits have not been determined.

\subsection{Radiolysis}

As discussed in the early ferrocyanide report (Burger 1984) the uncomplexed cyanide ion is rapidly destroyed under radiolysis conditions in aqueous solution. Considerable data are available (Touhill et al. 1969; Ogura et al. 1972; Behar 1974; Bielski and Allen 1977; Liaw and Woodbridge 1977; Draganic, Draganic, and Niketic 1977; and Shen-chu, Shao -hua, and Ji-lan 1981). The identified products include $\mathrm{CNO}^{-}, \mathrm{NH}_{3} . \mathrm{CHONH}_{2}$, and smaller amounts of $\mathrm{HCOO}^{-}, \mathrm{CO}_{2}$, urea, and probably $\mathrm{N}_{2}$. Results from this radiolysis study indicate $\mathrm{G}$ values (molecules decomposed per $100 \mathrm{eV}$ of energy absorbed) as high as 6 . It might be expected that the cyanate ion, $\mathrm{CO}_{2}$, and $\mathrm{N}_{2}$ would be the stable products. 
In the presence or absence of oxygen, the ferrocyanide ion is easily oxidized to ferricyanide by radiolysis. In deoxygenated systems the reverse reaction can also occur (Denaro and Jayson 1972). The oxidation of ferrocyanide to ferricyanide in the absence of oxygen was first demonstrated by Fricke and Hart (1935) where G (oxidation) was found to be 1.3.

Only brief preliminary experiments have been reported on the radiolytic stability of solid ferrocyanides (Martin, Burger, and Morgan 1985). These results suggested that the solid compounds may be very stable with respect to radiolytic decomposition. Any mechanism for decomposition is therefore likely to be through the aqueous phase. The major radiolytic products of water and their approximate yields (G values) at high $\mathrm{pH}$ are: $\mathrm{OH}, 2.9 ; \mathrm{H}_{2} \mathrm{O}_{2}, 0.8 ; \mathrm{H}_{2}, 0.4$; $\mathrm{H}, 0.6 ; \mathrm{e}_{\mathrm{aq}}^{-}, 3.0$ (Denaro and Jayson 1972). The first two are oxidizing, and the latter three are reducing. Subsequent reactions produce oxygen (from $\mathrm{H}_{2} \mathrm{O}_{2}$ ) and additional hydrogen (from the hydrated electron). Equilibria at the high $\mathrm{pH}$ will produce additional ionic species: $\mathrm{O}^{-}, \mathrm{HO}_{2}^{-}$, and $\mathrm{O}_{2}^{-}$. The radiolytic decomposition of nitrate ion producing both nitrite ion and oxygen, may add to the oxidative nature of the solution.

Although the amount of cyanide or ferrocyanide in solution is expected to be extremely small, the effectiveness of radiolytic oxidation reactions together with the very low solubility of the ultimate product, $\mathrm{Fe}(\mathrm{OH})_{3}$, provide a possible patn to the radiolytic destruction of ferrocyanide precipitates in the high $\mathrm{pH}$ environment.

\subsection{Conclusions}

The hexacyano-iron complexes, both $\mathrm{Fe}(\mathrm{II})$ and $\mathrm{Fe}(\mathrm{III})$, are exceptionally strong. The derived transition metal salts or double salts containing alkali metal ions are only slightly soluble. The nickel compounds examined in this study, those predicted to have been formed in the Hanford waste scavenging program, are typical examples. In spite of their stability towards most reagents under ambient conditions, they are all thermodynamically unstable towards oxidation and react explosively with oxidants such as nitrate or nitrite salts when heated to temperatures in excess of $200^{\circ} \mathrm{C}$.

These oxidation reactions are very complex and poorly understood. Information is needed on the mechanisms of the several steps in the reactions. On heating a mixture of ferrocyanide and nitrate or nitrite, a reaction normally begins at about $240^{\circ} \mathrm{C}$, but may occur well below $200^{\circ} \mathrm{C}$ in the presence of catalysts or organic compounds that may act as initiators. More information is needed on the effects of catalysts and diluents.

The peak reaction may occur in the vicinity of $320^{\circ} \mathrm{C}$; and the energy released is highly dependent on the course of the reaction. Complete oxidation yields about $3300 \pm 20 \% \mathrm{~J} / \mathrm{mol}$. Milligram quantities of a ferrocyanide nitrate/nitrite mix tend to explode over a wide range starting at about $280^{\circ} \mathrm{C}$.

Both the cyanide and hexacyano-iron complexes are unstable to radiolysis in aqueous solution, but the solid compounds appear to be resistant. However, no quantitative data exist. Very slow long term destruction of the cyanide precipitates may occur through aqueous processes. 


\subsection{Heat Transfer in Tanks Containing Ferrocyanide}

Due to the energetic chemical reaction that takes place when ferrocynide and nitrate/nitrite are heated, the temperatures in ferrocynide tanks are of great concern. As indicated above, if a mixture of ferrocyanide and nitrate/nitrite is heated to greater than $220^{\circ} \mathrm{C}$, an explosion can occur. In ferrocyanide-containing tanks, the principal heat source is the decay of ${ }^{137} \mathrm{Cs}$. Since this isotope was precipitated as the ferrocyanide, the existence of local concentrations of ferrocyanide solids (hot spots) represents the most credible scenario leading to an explosion. With this in mind, several thermal conduction calculations were performed to determine the size and temperature needed for a hot spot and what the probability was that the hypothetical hot spot could be located using the existing or new thermocouple trees.

Recent results from the temperature measurements in the ferrocynide tanks is shown in Table 5.1. The heat loads are conservative estimates and need to be revised. The temperatures measured in all of the tanks is are well below the temperatures of concern. These temperatures have been falling with time as the heat-generating isotopes decay. For example, the temperature in Tank 104-BY has been decreasing about $1.6^{c} \mathrm{C}$ per year.

It should be noted that although the temperatures shown in Table 5.1 are much lower than those of concern and these temperatures have been decreasing with time, the possibility of a hot spot exists because solid ferrocyanide material might have accumvlated in local areas during the period after the ferrocyanide wastes were generated and newly generated wastes were added to the tanks. Hot spots have been found in other Hanford waste tanis with heat loads in the range of $3 \cdot 10^{5}$ to $2 \cdot 10^{6} \mathrm{~W}$. Currently, no waste tank at the Hanford Site contains waste that generates more than $1.3 \cdot 10^{5} \mathrm{~W}$.

The possible existence of a hot spot causing the temperatures to increase into the range in which an explosion could be initiated has led to several attempts to model hot spots. Because Tank 104-BY contains the largest inventory of ferrocyanide and is the warmest of the ferrocyanidecontaining tanks, most of the modeling efforts have centered on this tank. Although the estimated heat load in Tank 104-BY is $4980 \mathrm{~W}$, the range has been estimated to be from 1760 to $5860 \mathrm{~W}$. In the modeling efforts, the heat load range for Tank 104-BY 1460 to $11700 \mathrm{~W}$ was used. The results from three of these modeling studies are summarized below.

\subsection{Modeling Calculations by D. A. Reynolds}

In the recent past, D. A. Reynolds performed HEATING-5 calculations on the heat load in Tank 104-BY to verify the results from earlier modeling calculations. In his model, Reyrivids assumed the heat-generating layer of ferrocyanide to be $2.3 \mathrm{~m}$ thick by $22.9 \mathrm{~m}$ in diameter with a $1.5 \mathrm{~m}$ non-heat-producing and insulating layer of waste above. Various heat rates and thermoconductivities were used in an attempt to match the observed temperatures in the tank. The best match was obtained when a heat load of $1900 \mathrm{~W}$ and a thermal conductivity of $1.13 \cdot 10^{4}$ $\mathrm{J} / \mathrm{m}^{2}$ were used. Using this information, Reynolds then calculated a probability of $2.9 \cdot 10^{-6}$ that a hot spot $1.2 \mathrm{~m}$ in diameter could exist with a temperature higher than $75^{\circ} \mathrm{C}$. This temperature represents a temperature that is 5 standard deviations above his mean calculated temperature. 
Table 5.1.

Temperatures and Estimated Heat Load in Ferrocyanide-Containing Tanks (Hanlon 1991)

\begin{tabular}{|c|c|c|}
\hline Tank & $\begin{array}{c}\text { Max. Temperature } \\
\left({ }^{\circ} \mathrm{C}\right)\end{array}$ & $\begin{array}{l}\text { Heat Load } \\
\text { (W) }\end{array}$ \\
\hline 102-BX & 19 & 2930 \\
\hline 106-BX & 20 & 2930 \\
\hline 110-BX & 19 & 2930 \\
\hline 111-BX & 22 & 2930 \\
\hline 101-BY & 24 & 2400 \\
\hline 103-BY & 22 & 2520 \\
\hline 104-BY & 54 & 4980 \\
\hline 105-BY & 46 & 11040 \\
\hline 106-BY & 56 & 3570 \\
\hline 107-BY & 30 & 4250 \\
\hline 108-BY & 39 & 6740 \\
\hline 110-BY & 51 & 7380 \\
\hline 111-BY & 29 & 10000 \\
\hline 112-BY & 26 & $<2930$ \\
\hline $108-C$ & 25 & 2930 \\
\hline $109-C$ & 23 & 2930 \\
\hline $111-C$ & 24 & $<2930$ \\
\hline $112-C$ & 29 & $<2930$ \\
\hline $101-\mathrm{T}$ & 22 & $<2930$ \\
\hline 118-TX & 23 & 1440 \\
\hline 101-TY & 21 & $<2930$ \\
\hline 103-TY & 18 & $<2930$ \\
\hline
\end{tabular}


The temperatures needed to initiate an explosion are in the range of 30 standard deviations above the mean temperature in Reynolds calculations, indicating that the probability is extremely low that a 1.2-m hot spot exists with a temperature high enough to be of concern. Reynolds used the results of these calculations to determine how many thermocouple trees would have to be placed in Tank 104-BY to locate a hypothetical $1.2-\mathrm{m}$ hot spot. Sampling grid statistics indicated that a square grid with $0.23-\mathrm{m}$ on a side would be necessary to detect a 1.2 -m-diameter hot spot with $90 \%$ confidence. In a 22.9 -m-diameter tank, this sampling grid would mean about 75 thermocouple trees would need to be installed. Since there are not 75 penetrations in which thermocouples could be placed, the calculations indicated that it would be unlikely that a hot spot could be found. A much finer grid (more thermocouple trees) would be needed to locate a hot spot smaller than $1.2 \mathrm{~m}$ in diameter.

The general conclusions from these studies are that the heat rate in Tank 104-BY is about $1900 \mathrm{~W}$ and there is a very low probability that a hot spot could be located using either the existing thermocouple tree or the maximum number of trees that could potentially be placed in the tank.

\subsection{Modeling Calculations by J. J. Barker}

Barker attempted to model the hypothetical hot spot in Tank 104-BY first using finite element analysis and then using the analytical expression for a finite heat source surrounded by a solid. He assumed cylindrical geometry for the heat source and used the equation from Carslaw and Jaeger (1959):

$$
v=\frac{A}{\rho c} \int_{0}^{t}\left[1-e^{-a^{2} / 4 D u}\right] \operatorname{erf} \frac{b}{\sqrt{4} D u} d u
$$

where:

$\mathrm{v}$ is maximum temperature rise in the cylinder

$\rho$ is density

$c$ is specific heat

$A$ is heat generation rate per unit time per unit volume

$\mathrm{D}$ is diffusivity

$t$ is time

$u$ is time

Assuming two volumes for the heat source, $3.8 \cdot 10^{-3} \mathrm{~m}^{3}$ and $0.03 \mathrm{~m}^{3}$, each with a heat load equal to 10 times the surrounding material, Barker calculated the maximum heat rise for the cylinder would be about $1^{\circ} \mathrm{C}$ and $5.6^{\circ} \mathrm{C}$, respectively. The thermoconductivity used by Barker was in the range of that used by Reynolds, $1.13 \cdot 10^{4} \mathrm{~J} / \mathrm{m}^{2}$. 
These results indicate that even for a hot spot with a heat load equal to 10 times that of the surrounding material, the size would have to be very large, hence detectable, in order for the temperature of the hot spot to approach the temperature needed to initiate an explosion.

\subsection{Modeling Calculations by J. M. McLauren}

The existence and properties of a hypothetical hot spot were investigated by McLauren using an updated, relative to the version used by Reynolds, version of HEATING-5. In general, modifications were made to the code were so that two and three dimensional simulations could be performed. As in the previous study, the heat load of a layer of ferrocyanide and thermal conductivity of the surrounding material were varied so that the calculated temperature profiles matched the observed temperature profile in Tank 104-BY. These calculations allowed McLauren to make an estimate of the heat load (2930 W) and the thermal conductivity [ $<2$ $\left.\mathrm{W} /\left(\mathrm{m}^{2} \cdot \mathrm{K}\right)\right]$ in the tank. These parameters were then used in the calculation of the temperature of the hypothetical hot spot.

Results from these calculations indicated that a hot spot, nominally $1.2 \mathrm{~m}$ in diameter, would have to contain 55 times more heat load than the surrounding material in order for the hot spot material to reach temperatures of concern. Voids in the waste were also considered and found not to hinder the transfer of heat.

By extending the calculations, McLauren was able to calculate the impact of a hot spot deep within the waste on the surface temperature. This was done to determine if infrared sensors could be used to detect the presence of a hot spot. The results indicated that the temperature rise could be detected, but the depth of the hot spot could not be determined unambiguously. The ambiguity arose because the deeper the hot spot, the more diffuse would be the temperature rise on the surface.

\subsection{Conclusions}

Results from the three thermal calculations indicate that the probability of detecting a hot spot of significance is very low. Locatin trees is unlikely because there aren't enough ports through which to insert the number of thermocouple trees needed to detect a hot spot. In addition, the probability of having a hot spot with sufficiently high temperature to be of concern was also very low. Each of the modeling exercises carried out indicated that the size of the hot spot had to be unrealistic relative to the potential mechanical mechanisms in the tank.

Additional heat transfer calculations are being performed using newer finite element codes to better model the thermal behavior of the ferrocyanide wastes. 


\subsection{Unresolved Scientific Issues}

In order of their priority, the principal unresolved scientific issues are:

- What are the composition and properties of actual Hanford tank ferrocyanide wastes?

Concerns about the potential explosive reactions of "ferrocyanide" solids in Hanford singleshell tanks would likely largely disappear if the "ferrocyanide" sludges had, over several decades, converted to other, nonreactive compounds. Such conversion may have occurred as the result of exposure of the ferrocyanide precipitates to gamma radiation or of exposure of the solids to highly alkaline solutions. Even if the original ferrocyanides are still largely present, it is absolutely essential to obtain representative samples of the actual tank solids to determine their composition, reaction with solid nitrate and nitrite salts, and the effect of diluents on the reaction.

- What is the lowest temperature at which credible proportions of various ferrocyanide compounds and $\mathrm{NaNO}_{3}$ and $\mathrm{NaNO}_{2}$ will 1) begin to react and 2) react explosively?

This information, for actual solids in the ferrocyanide tanks, is critical to establishing exactly what temperature regime needs to be maintained in the relevant single-shell tanks to ensure that no explosive reaction: can occur. Because samples of actual ferrocyanide solids are not now available and likely will not be available for some time, experimental work needs to focus on determination of threshold temperatures for onset of reactions between simulated ferrocyanide solids, both irradiated and nonirradiated, and nitrate and nitrite salts.

- What are the kinetics and energetics of reartions of ferrocyanide compounds with $\mathrm{NaNO}_{3}$ and $\mathrm{NaNO}_{2}$ ?

Continued safe interim containment of ferrocyanide wastes in single-shell tanks requires not only knowledge of threshold ferrocyanide-nitrate (or nitrite) reactions but also knowledge of the rate of such reactions, the amounts of energy evolved and the effect of diluent and catalyst concentrations. Obviously, it is desirable (and eventually necessary) to gain such knowledge by tests with actual waste samples. But, until actual waste samples are available, experimental work should and must be done with simulated ferrocyanide wastes, over a wide range of conditions, to gain a bounding knowledge of kinetics and energetics of ferrocyanidenitrate (or nitrite) reactions.

- What is the stability, toward decomposition, of nickel and other ferrocyanide compounds to ionizing radiation?

A single early experiment by Martin, Burger, and Morgan (1985) indicated that radiation doses as high as $10^{8}$ rad did not appear to bring about any discernible effect on the stability of a nickel ferrocyanide precipitate. Additional radiation experiments should be performed to verify (or refute) the early result and to establish whether or not radiation doses equivalent to those received by actual ferrocyanide wastes result in radiolytic decomposition of nickel 
ferrocyanide compounds. If significant radiolytic decomposition is observed, the experimental work should be expanded to determine the type and amount of the major radiolytic degradation products.

- What are suitable routine analytical methods for determining the presence and concentration of ferrocyanide ion in retrieved solid ferrocyanide wastes and in aqueous solutions of such waste?

Eventually, it will be possible to core sample all the single-shell tanks that contain ferrocyanide solids. A suitable analytical method for determining (safely) the presence and amount of ferrocyanide in such solids is essential to characterize them and to study their reactions. Eventually, also, ferrocyanide wastes will be retrieved from some, perhaps all, of the tanks for treatisent and final disposal. Tre tment prior to disposal will likely involve dissolution in appropriate aqueous media (e.g., concentrated $\mathrm{H}_{2} \mathrm{SO}_{4}$ or $\mathrm{H}_{3} \mathrm{PO}_{4}$ ). Again, it will be necessary to analyze the aqueous dissolver solution for its content of ferrocyanide ion.

- Are there precursor reactions and products that can be used as an indicator of ferrocyanide$\mathrm{NaNO}_{3}-\mathrm{NaNO}_{2}$ reactions?

Work at Westinghouse Hanford Co. indicates that the possibility of finding a hot spot in the tanks is low. Placing thermal imaging systems in the tank plenum to monitor the surface may provide more information, but, even if this method can be shown to be reliable and effective, a second and independent system will be needed to confirm that a runaway reaction is imminent. Reliable confirmatory information might be the analysis of the gases in the tank plenum. Certain key gaseous species might be useful as indicators of the initial stages of a runaway reaction. 


\subsection{References}

Abrams, R. B. 1956. Metal Recovery Waste Scavenging Process, HW-43066, Hanford Atomic Works Operation, Richland, Washington.

American Cyanamid. 1953. The Chemistry of the Ferrocyanides. Am. Cyanamid Co., New York.

Backman, G. E., E. M. Johnston, and H. C. Rathvon. 1964. Chemical Processing Department Hazard Evaluation of In-Tank Solidification, RL-SEP-65, Hanfoid Atomic Products Operation, Richland, Washington.

Barin, I. 1989. Thermochemical Data of Pure Substances. VCH Verlagsgesellschaft, Weirheim, Germany.

Behar, D. 1974. "Pulse Radiolysis Study of Aqueous Hydrogen Cyanide and Cyanide Solutions." J. Phvs. Chem. 78(26):2660.

Bielski, B. H. J. and A. O. Allen. 1977. "Radiation Chemistry of Aqueous Cyanide Ion." J. Am. Chem. Sci. 99:5931.

Boucher, F. W., Jr., and W. T. Ingalls. 1955. In-Tank Process Description, HW-34487, Hanford Atomic Products Operation, Richland, Washington.

Burger, L. L. 1984. Complexant Stability Investigations. Task 1. Ferrocyanide Solids, PNL5441, Pacific Northwest Laboratory, Richland, Washington.

Burger, L. L. and R. D. Scheele. 1988. Interim Report on Cyanide Safety Studies, PNL-7175, Pacific Northwest Laboratory, Richland, Washington.

Burger, L. L., and R. D. Scheele. 1990. The Reactivity of Cesium Nickel Ferrocyanide Towards Nitrate and Nitrite Salts. PNL-7550, Pacific Northwest Laboratory, Richland, Washington.

Burns, R. E., R. L. Brandt, and W. E. Clifford. 1954. Removal of Cesium from Uranium Recoverv Process Wastes, HW-31442, Hanford Atomic Products Operation, Richland, Washington.

Carslaw, H. S., J. C. Jaeger. 1959. Conduction of Heat in Solids, 2nd Ed, Oxford University Press, London, England.

Ceranic, T. 1978. "The Structure Model oi an Inorganic Ion Exchanger Cobalt(11)-hexacyanoferae(II). Zeitschrift for Naturferischung.

Chadwick, B. M., and A. G. Sharpe. 1966. "Transition Metal Cyanides and Their Complexes" in Advances in Inorganic Chemistry and Radiochemistry. Vol. 8. H. J. Emeleus and A. G. Sharpe, Eds., Academic Press, New York. 
Cooper, V. R. 1957. Chemical Research and Development Monthly Report and Quarterly Synopsis (U). HW-49419C-DEL, Hanford Atomic Products Operation, Richland, Washington.

Denaro, A. R., and G. G. Jayson. 1972. Fundamentals of Radiation Chemistry. Buttermoths, London.

Draganic, Z. D., I. G. Draganic, and V. Niketic. 1977. "The Radiation Chemistry of Aqueous Solutions of Ammonium and Sodium Cyanides in the Megarad Dose Range." Rad. Res. 69:223-229.

Eiter, K, O. Vogl, and H. Michl, "Cyanide Safety Explosives," Austrian Patent 176784 (1953), CA 48, 1004 (1954).

Finch, L. W. 1953. Test Frocedure to Evaluate Scavenging of TBP Plant Solvent Extraction Waste with Nickel Ferrocyanide, HW-29383, Hanford Atomic Products Operation, Richland, Washington.

Fricke, H. and E. J. Hart. 1935. "The Oxidation of the Ferrocyanide, Arsenite and Selenite Ions by the Irradiation of Their Aqueous Solutions with X-Rays." J. Chem. Phys. 3:596.

Hanlon, B. M. 1991. "Tank Farm Surveillance and Waste Status Report for December 1990", WHC-EP-0182-33, April 1991, Westinghouse Hanford, Richland, Washington.

Henkin, H., and R. McGill. 1952. Ind. Eng. Chem. 44:1391.

Hepworth, J. L., E. D. McClanahan, and R. L. Moore. 1957. Cesium Packaging StudiesConversion of Zinc Ferrocyanide to a Cesium Chloride Product, HW-48832, Hanford Atomic Products Operation Co., Richland, Washington.

Kissinger, H. E. 1957. "Reactive Kinetics in Differential Thermal Analysis," Analvtical Chemistry 29:1702.

Liaw, G-S., and D. D. Woodbridge. 1977. "Effects of Gamma Radiation on Aqueous Solutions of Cyanide." Bull. Env. Contam. \& Toxic 17(6):714.

Loos-Neskovic, C., M. Federoft, E. Garnier and F. Gravercal. 1948. "Zinc and Nickel Ferrocyanides: Preparation Composition and Structure," Talanta 31(12):1133.

Loos-Neskovic, C., M. Fedenoft, and E. Garnier. 1989. "Preparation, Composition and Structure of Some Nickel and Zinc Ferrocyanides: Experimental Results," Talanta 36(7):749.

Martin, E. C., L. L. Burger, and L. G. Morgan. 1985. Radiation Stability of $\mathrm{Cs}_{2} \mathrm{NiFe}_{(\mathrm{CN})_{6}}$. PNL-7174, Pacific Northwest Laboratory, Richland, Washington. 
Mihalik, L. A. 1989. "Document No. 8857323, Information Concerning Ferrocyanides in SingleShell Tanks," Westinghouse Hanford Co., Richland, Washington.

Mishima, J., S. L. Sutter, and K. A. Halley. 1986. Potential Radiological Impacts of Upperbound Operational Accidents During Proposed Waste Disposal Alternatives for Hanford Defense Waste, PNL-5356, Pacific Northwest Laboratory, Richland, Washington.

Mound Laboratory. 1951. Decontamination of Process Waste Solutions Containing Fission Products by Adsorption and Coprecipitation Methods, MLM-621, Mound Laboratories, Monsanto Chemical Corp., Miamisburg, Ohio.

National Board of Fire Underwriters. 1950. Research Report No. 2, Fire Prevention and Engineering Standards. Potential Standards in Molten Salt Baths for Heat Treatment of Metals. New York, New York.

Ogura, H., T. Fujimura, S. Murozono, K. Hirano, and M. Kondo. 1972. "Radiolysis of Hydrogen Cyanide in an Aqueous System, (III), pH Dependence of Radiolysis." J. Nucl. Sci. \& Tech. 9:(6):339-343.

Pauling, L. 1939. The Nature of the Chemical Bond. Cornell University Press, Ithica, N.Y.

Sax, I. N. 1957. Dangerous Properties of Industrial Materials. Reinhold, New York, New York.

Schmidt, W. C., and M. H. Stedwell. 1954. Production Test 221-T-18 Scavenging of First-Cycle Waste, HW-33252, Hanford Atomic Products Operation, Richland, Washington.

Schulz, W. W. 1955. Decontamination of Uranium Recovery Process Stored Wastes. Interim Report, HW-36717, Hanford Atomic Proucts Operation Co., Richland, Washington.

Schulz, W. W. 1989. Meeting Minutes: Potential Exothermic Chemical Reactions in Waste Tanks, WHC-MR-0055, Rockwell Hanford Operations, Richland, Washington.

Shen-chu, Q., Y. Shao-hua, and W. Ji-lan. 1981. "Radiolysis of Aqueous Solution of Cyanide Ion." Radiat. Phys. Chem. 18(3-4):0793-0805.

Sharpe, A. G. 1976. The Chemistry of Cyano Complexes of Transition Metals. Academic Press, New York, N.Y.

Silleń, L. G., and A. E. Martell. 1964. Stability Constants of Metal-Ion Complexes. The Chemical Society, London, England. 
Sloat, R. J. 1955. In-Farm Scavenging Operating Procedures and Control Data, HW-38955, Hanford Atomic Products Operation Co., Richland, Washington.

Smith, R. E. and E. A. Coppinger. 1954. Nickel Ferrocyanide Scavenging Flowsheet for Neutralized Concentrated RAW, HW-33536, Hanford Atomic Products Operation Co., Richland, Washington.

Stedwell, M. J. 1954. Evaluation of Nickel Ferrocyanide Scavenging of Uranium Recovery Plant Solvent Extraction Waste, HW-31428, Hanford Atomic Products Operation, Richland, Washington.

Tananaev, I. V., M. A. Glushkova, and G. B. Seifer. 1956. "The Solubility Series of Ferrocyanides," J. Inorg. Chem. USSR, I(1):66.

Touhill, C. J., E. C. Martin, M. P. Fujihara, D. E. Olesen, J. E. Stein, and G. McDonald. 1969. "The Effects of Radiation on Chicago Sanitary District Municipal and Industrial Waste Waters." J. Water Pollution Control Federation, 41:R44.

Van Tuyl, H. H. 1957a. Recovery of Cesium from PUREX Plant Wastes by Metal Ferrocyanide and Ferricyanides. I. Tracer Scale Laboratory Investigations, HW-48829, Hanford Atomic Products Operation, Richland, Washington.

Van Tuyl, H. H. 1957b. Recovery of Cesium from PUREX Plaint Wastes by Metal Ferrocyanide and Ferricyanides. II. Full Level Laboratory Investigations, HW-48830, Hanford Atomic Products Operation, Richland, Washington.

Wagman, D. D., W. H. Evants, V. B. Parker, R. S. Schumm, I. Halow, S. M. Bailey, K. L. Churney, and R. L. Nuttall. 1982. "The NBS Tables of Chemical Thermodynamic Properties." J. Phys. Chem. Ref. Data 11(2).

Wirta, R. W., and O. H. Koski. 1957. Flowsheet No. 1 Cs Isolation and Packaging. HW-50241, Hanford Atomic Products Operation, Richland, Washington. 


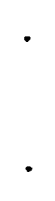


No. of

Copies

\section{OFFSITE}

12 DOE/Office of Scientific and Technical Information

J. Tseng

U.S. Department of Energy

EM-35

Trevion II

Washington, DC 20585-0002

C. Abrams

1987 Virginia

Idaho Falls, ID 83404

J. Antizzo

U.S. Department of Energy

EM-351

Trevion II

Washington, DC 20585-0002

E. C. Ashby

225 North Avenue

Boggs Chemistry Building

Georgia Institute of

Technology

Atlanta, GA 30332

K. Bandyopadhyay

Building 129

Brookhaven National Laboratory

Upton, NY 11973

N. E. Bibler

Westinghouse Savannah River

Bldg. 773A, Room 108

Aiken, SC 29802

D. Campbell

Oak Ridge National Laboratory

P.O. Box 2008, MS 6268

Oaik Ridge, TN 37831-6268
No. of

Copies

\section{F. Carlson}

6965 North, 5th West

Idaho Falls, ID 83401

P. d'Entremont

Westinghouse Savannah River

P.O. Box 616, Bldg. 703-H

Aiken, SC 29802

R. Daniels

SAIC

20030 Century Blvd.

Suite 201

Germantown, MD 20878

M. First

295 Upland Avenue

Newton Highlands, MA 02161

C. Forsberg

Room 24-109

77 Massachusetts Avenue

Cambridge, MA 02139

E. J. Hart

2115 Hart Road

Port Angeles, WA 98362

P. Hogroian

SAIC

20030 Century Blvd., Suite 201

Germantown, MD 20874

E. P. Horwitz Chemistry Division

Argonne National Laboratory

Argonne, IL 60439
A. Hoskins
WINCO, MS-5217
P.O. Box 4000
Idaho Falls, ID $83403-4000$ 
B. Hudson

Lawrence Livermore National Laboratory, L-221

P.O. Box 808

Livermore, CA 94550

M. Kazimi

Room 24-102

77 Massachusetts Avenue Cambridge, MA 02139

\section{P. Kiang}

BDM, Trevion I, Suite 300

12850 Middlebrook Road

Germantown, MD 20874

T. Kress

P.O. Box 2009

MS 8088, Building 9108

Oak Ridge, TN 37381

T. Larson

Los Alamos National

Laboratory, M-1

MS C-920, P.O. Box 1663

Los Alamos, NM 87545

D. Oakley

Los Alamos National

Laboratory

University of California,

Suite 310

409 12th Street, SW

Washington, DC 20024-2188

D. Ploetz

West Valley Nuclear

Services Co.

P.O. Box 191, MS 305

West Valley, NY 14171-0191

M. Reich

Building 129

Brookhaven National Laboratory

Upton, NY 11973
J. Saveland

20030 Century Blvd., Suite 201

Germantown, MD 20874

G. Schmauch

Air Products \& Chemicals, Inc. 7201 Hamilton Blvd.

Allentown, PA 18195-1501

W. W. Schulz

727 Sweetleaf Drive

Wilmington, DE 19808

B. Schutte

EG\&G Idaho, Inc.

P.O. Box 1625

Idaho Falls, ID $83415-3940$

D. D. Siemer

WINCO

IRC, MS 2207

Idaho Falls, ID 83403

S. Slezak

Sandia National Laboratories, Division 6463

P.O. Box 5800

Albuquerque, NM 87185

H. Sullivan

Los Alamos National

Laboratory, N-6, MS-K557

P.O. Box 1664

Los Alamos, NM 87545

C. Terrell

U.S. Department of Energy, Bldg. 704-S

P.O. Box A

Aiken, SC 29801

W. J. Thomson

Department of Chemical Engineering

Washington State University

Pullman, WA 99164 
No. of

Copies

A. S. Veletsos

5211 Paisley

Houston, TX 77096

H. Walter

U.S. Department of Energy

EM-343

Trevion II

Washington, DC 20585-0002

M. Walter

U.S. Department of Energy

EM-35

Trevion II

Washington, DC 20845-0002

D. Wiffen

U.S. Department of Energy

EM-35

Trevion II

Washington, DC 20585-0002

G. Woodall

U.S. Department of Energy, MS-1139

785 DOE Place

Idaho Falls, ID 83402

\section{ONSITE}

5 DOE Field Office, Richland

R. F. Christensen, A4-02

R. E. Gerton, A5-21

G. Rosenwald, A5-21

B. J. Tucker, A4-35

Reading Room A1-65

36 Westinghouse Hanford Company.

H. Babad, B2-15

D. G. Baide, R1-51

D. B. Bechtold, T6-50
No. of

Copies

M. L. Bell, T5-50

R. M. Black, R1-19

R. J. Bliss, B3-04

H. R. Brager, L5-03

W. F. Brehm, N2-01

R. J. Cash, B3-68

D. L. Deichman, H0-03

G. L. Dunford, R1-51

K. A. Gasper, B3-68

W. H. Hamilton, R2-40

D. L. Herting, T6-50

G. D. Johnson, L5-03 (5)

N. W. Kirch, R2-11

W. D. Leggett, L5-04 (5)

R. M. Marvsich, H5-32

L. D. Muhlestein, N1-28

D. A. Reynolds, R2-11 (5)

W. G. Ruff, R2-53

M. H. Shannon, B1-35

D. D. Stepnewski, N1-31

D. D. Wodrich, R2-23

50

R. T. Allemann, K5-19

T. H. Dunning, K2-18

R. T. Hallen, K2-12

M. S. Hanson, K1-51

B. M. Johnson, Jr., K5-02 (5)

D. K. Lemon, K2-28

G. B. Mellinger, P7-18

L. G. Morgan, P8-07

L. R. Pederson, K2-44

J.T.A. Roberts, K1-73

R. D. Scheele, P7-25

J. C. Spanner, K2-31

D. M. Strachan, K2-44 (25)

R. W. Stromatt, P7-22

D. S. Trent, K1-82

H. H. Van Tuyl, P7-22

Publishing Coordination

Technical Report Files (5) 

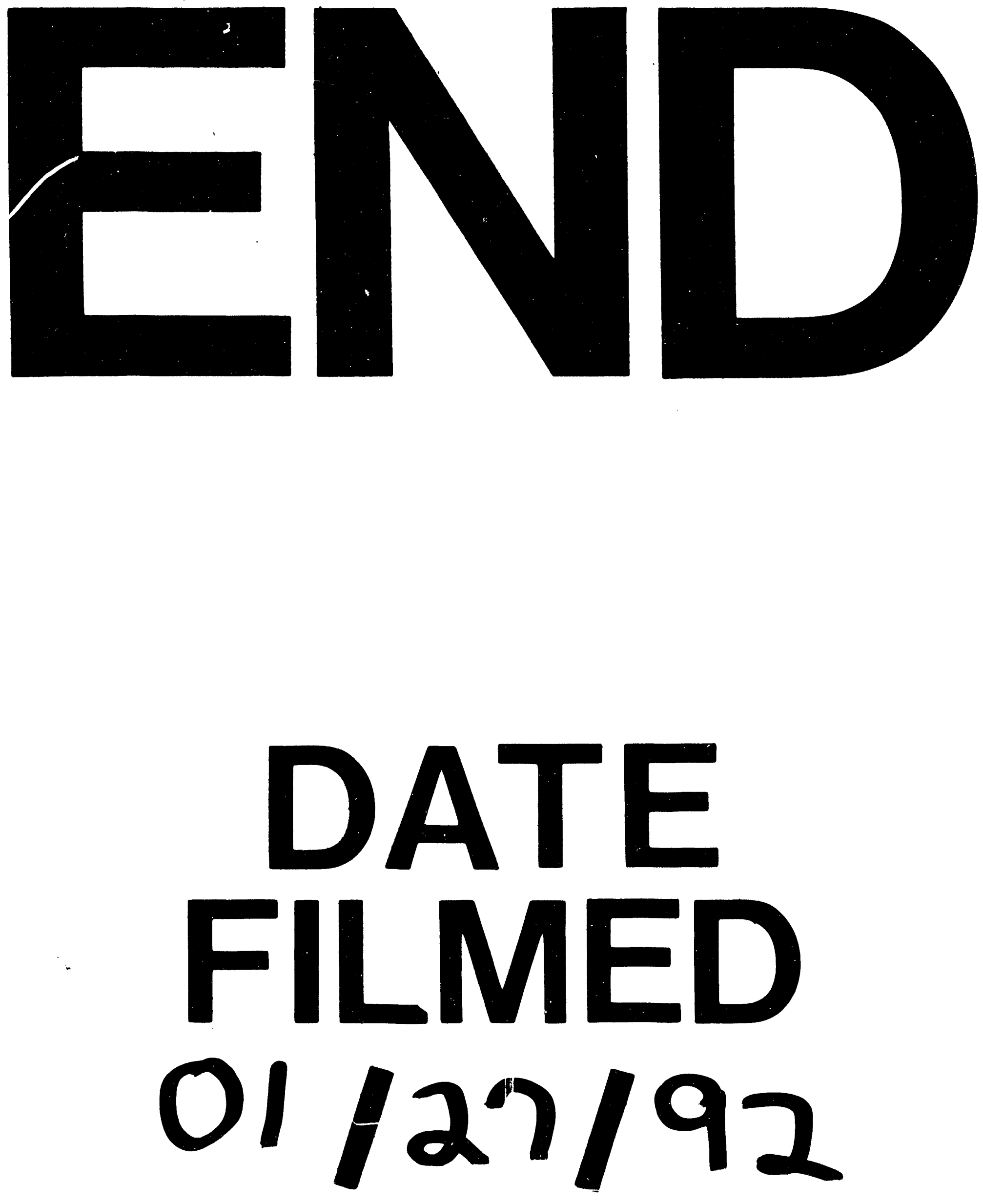

1 
